\title{
Modeled Trends in Antarctic Sea Ice Thickness
}

\author{
PAUl R. Holland AND Nicolas BRUNEAU* \\ British Antarctic Survey, Cambridge, United Kingdom \\ CLARE ENRIGHT \\ Tyndall Centre for Climate Change Research, University of East Anglia, Norwich, United Kingdom \\ MARTIN LOSCH \\ Alfred Wegener Institute for Polar and Marine Research, Bremerhaven, Germany \\ NATHAN T. KURTZ \\ NASA Goddard Space Science Center, Greenbelt, Maryland \\ RON KWOK \\ Jet Propulsion Laboratory, Pasadena, California
}

(Manuscript received 30 May 2013, in final form 17 January 2014)

\begin{abstract}
Unlike the rapid sea ice losses reported in the Arctic, satellite observations show an overall increase in Antarctic sea ice concentration over recent decades. However, observations of decadal trends in Antarctic ice thickness, and hence ice volume, do not currently exist. In this study a model of the Southern Ocean and its sea ice, forced by atmospheric reanalyses, is used to assess 1992-2010 trends in ice thickness and volume. The model successfully reproduces observations of mean ice concentration, thickness, and drift, and decadal trends in ice concentration and drift, imparting some confidence in the hindcasted trends in ice thickness. The model suggests that overall Antarctic sea ice volume has increased by approximately $30 \mathrm{~km}^{3} \mathrm{yr}^{-1}\left(0.4 \% \mathrm{yr}^{-1}\right)$ as

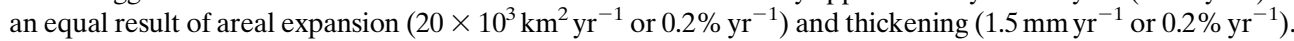
This ice volume increase is an order of magnitude smaller than the Arctic decrease, and about half the size of the increased freshwater supply from the Antarctic Ice Sheet. Similarly to the observed ice concentration trends, the small overall increase in modeled ice volume is actually the residual of much larger opposing regional trends. Thickness changes near the ice edge follow observed concentration changes, with increasing concentration corresponding to increased thickness. Ice thickness increases are also found in the inner pack in the Amundsen and Weddell Seas, where the model suggests that observed ice-drift trends directed toward the coast have caused dynamical thickening in autumn and winter. Modeled changes are predominantly dynamic in origin in the Pacific sector and thermodynamic elsewhere.
\end{abstract}

\section{Introduction}

Arctic sea ice extent has declined rapidly in recent decades $\left(-52 \times 10^{3} \mathrm{~km}^{2} \mathrm{yr}^{-1}\right.$ for 1979-2010), but Antarctic

* Current affiliation: RMS Ltd., London, United Kingdom.

Corresponding author address: Paul Holland, British Antarctic Survey, High Cross, Madingley Rd., Cambridge, CB3 0ET, United Kingdom.

E-mail: p.holland@bas.ac.uk sea ice extent has slowly increased $\left(+17 \times 10^{3} \mathrm{~km}^{2} \mathrm{yr}^{-1}\right)$ over the same period (Cavalieri and Parkinson 2012; Comiso and Nishio 2008; Parkinson and Cavalieri 2012; Zwally et al. 2002), raising fundamental questions of why the two poles have evolved so differently in the context of climate change. The small overall Antarctic increase in ice area is actually the residual of a coherent pattern of much larger regional increases and decreases that almost compensate each other. These large local areal changes (up to $2 \% \mathrm{yr}^{-1}$ increase and decrease, or $60 \%$ total over $30 \mathrm{yr}$; Turner et al. 2009) can also be

DOI: 10.1175/JCLI-D-13-00301.1

(C) 2014 American Meteorological Society 
viewed as changes in the length of the ice season (up to 3 days $\mathrm{yr}^{-1}$, or 3 months in total; Stammerjohn et al. 2012). The local changes are of the same magnitude as those in the Arctic, which does not feature the regions of ice expansion that, in the Antarctic, more than offset the regions of loss.

It is currently unclear exactly what causes the regional pattern of changes that produces the overall increase in ice cover. Proposed drivers include changes in atmospheric temperature or wind stress (Lefebvre and Goosse 2005; Liu et al. 2004; Turner et al. 2009), precipitation (Liu and Curry 2010), ocean temperature (Jacobs and Comiso 1997), atmosphere and ocean feedbacks (Stammerjohn et al. 2008; Zhang 2007), and increased freshwater flux from the Antarctic Ice Sheet (Bintanja et al. 2013). Recent work has shown that the trends in Antarctic ice concentration are associated with trends in ice drift, and that both are caused by changes in near-surface winds through a combination of dynamic and thermodynamic effects (Holland and Kwok 2012). However, the ultimate cause of the relevant wind changes remains uncertain.

The current generation of coupled climate models is unable to capture the increase in overall Antarctic sea ice extent, instead hindcasting a decline in ice cover of a similar magnitude to their modeled Arctic (Turner et al. 2013). This suggests that important deficiencies exist in our understanding of ice and climate physics that will be relevant to the prediction of climate at both poles. The model projections of most aspects of Antarctic climate are questionable if they cannot reproduce past observations of sea ice extent, since it is one of the bettermonitored polar climate variables. Improved climate models are also required to answer top-level questions about past changes in Antarctic sea ice that are of vital importance to policy makers. For example, it is unclear why Antarctic sea ice is not rapidly declining in response to increased greenhouse gas concentrations and depletion of stratospheric ozone, both of which are found to decrease Antarctic sea ice in coupled climate models (Bitz et al. 2006; Sigmond and Fyfe 2010). Several studies have suggested that the observed increase is an unlikely result of natural variability, which would consequently only be captured by a small proportion of simulations (Mahlstein et al. 2013; Polvani and Smith 2013; Swart and Fyfe 2013). However, this result is marginal, valid only for the annual-mean circumpolar trend (Swart and Fyfe 2013), and relies upon the models having realistic natural variability, which is not the case (Turner et al. 2013; Zunz et al. 2013). In this study we investigate the Antarctic ice trends further in a quest to provide additional insight into these model weaknesses.

A critical gap in our understanding of Antarctic sea ice and its trends is caused by the relative paucity of
Antarctic ice thickness data. Though spatially widespread, in situ observations are severely lacking in spatial and temporal detail (Worby et al. 2008). Ice thickness can be determined from satellite altimetry by measuring the ice freeboard and assuming that the ice is freely floating with some choice of ice, snow, and seawater properties. Radar altimeters have provided a relatively long record of ice thickness in the Arctic, but are subject to variable snow penetration in the Antarctic that currently precludes the reliable determination of ice freeboard (Giles et al. 2008). The freeboard of Antarctic ice and snow can be accurately measured using laser altimeters, and this can be converted to ice thickness using independent estimates of snow thickness and snow and ice density (Markus et al. 2011; Xie et al. 2013; Zwally et al. 2008). Recent studies demonstrate that ice thickness can be derived to a reasonable level of accuracy using the simple assumption that the snow-ice interface is at sea level (Kurtz and Markus 2012; Ozsoy-Cicek et al. 2013). However, the available laser altimeter data are limited in temporal coverage, and therefore unable to provide reliable trends in ice thickness. Instead, we use a coupled ice-ocean model to investigate the ice thickness trends and their drivers.

Models have previously been used to study various sensitivities of Antarctic sea ice, including the effects of surface precipitation (Powell et al. 2005), winds (Stossel et al. 2011), and ice-shelf meltwater (Hellmer 2004). Models have also been used to assess linkages between sea ice variability and large-scale climate modes (Lefebvre and Goosse 2005, 2008). Several such models have been validated against ice observations, including those of ice thickness, with notable success (Fichefet et al. 2003a; Losch et al. 2010; Timmermann et al. 2002, 2004, 2005, 2009). However, only a few model studies consider changes in Antarctic sea ice thickness or volume.

Proposing an ocean feedback on increasing Antarctic sea ice, Zhang (2007) simulated a 1979-2004 increase in ice volume of $200 \mathrm{~km}^{3} \mathrm{yr}^{-1}$. The mean ice area of $10^{7} \mathrm{~km}^{2}$ thus implies an Antarctic-mean thickening of $2 \mathrm{~cm} \mathrm{yr}^{-1}$, or $0.5 \mathrm{~m}$ over the period, which seems unfeasibly large. This simulation had many shortcomings: overestimation of annual-mean ice volume by a factor of 2 (Kurtz and Markus 2012); overestimation of area trend by a factor of 3; disagreement with observed spatial pattern of concentration trends; and disagreement with observed temporal variability in total ice extent. Fichefet et al. (2003a) found an area increase of $11 \times 10^{3} \mathrm{~km}^{2} \mathrm{yr}^{-1}$ over 1958-99 but no appreciable trend in ice thickness, though considerable wind-driven decadal variability in ice thickness and area were identified. Fichefet et al. (2003b) investigated 1955-2001 area and volume trends, finding an overall decrease of $9 \times 10^{3} \mathrm{~km}^{2} \mathrm{yr}^{-1}$ and an increase of 
$11 \mathrm{~km}^{3} \mathrm{yr}^{-1}$, respectively. However, reanalysis-forced models should be treated with extreme caution prior to the onset of satellite sounding data assimilation in late 1978 (Bromwich and Fogt 2004), and the latter model produces no trend in ice area during 1978-2001. Timmermann et al. (2005) report little modeled trend in ice area or volume during 1977-99, attributing this to their spinup technique of repeating the reanalysis forcing twice. Timmermann et al. (2009) model an ice area increase of $11 \times 10^{3} \mathrm{~km}^{2} \mathrm{yr}^{-1}$ for 1979-2006 but do not report the corresponding volume trend. Crucially, the latter four studies do not show the spatial distribution of ice concentration trends, so it is impossible to assess whether the physical processes driving their overall trends are realistic.

A recent modeling study by Zhang (2014) specifically investigates the effect of changes in winds on Antarctic ice volume. The study finds an increase in ice volume of $69 \mathrm{~km}^{3} \mathrm{yr}^{-1}$ over $1979-2010$, but at $15 \times 10^{3} \mathrm{~km}^{3}$ the annual mean ice volume in this model is approximately twice that inferred from observation (Kurtz and Markus 2012), which casts significant doubt on the value of the volume trend. Since the ice extent is reasonable, this implies that the ice thickness is approximately twice the true value. The study does not examine in detail the changes during different seasons, in different regions, or the thermodynamic and dynamic mechanisms underlying the changes.

Probably the most reliable estimate of recent ice volume trends are from the model of Massonnet et al. (2013), which formally optimizes the estimate by assimilating ice concentration data using an ensemble Kalman filter. The results show an overall 1980-2008 increase in ice volume of $36 \pm 34 \mathrm{~km}^{3} \mathrm{yr}^{-1}$, with a regional pattern of ice-thickness trends that are closely related to the changes observed in ice concentration. The use of data assimilation has strengths and weaknesses; the results should be quantitatively as reliable as possible, but the adjustments made to the model state vector do not have a directly physical origin, and none of the ice or ocean variables are conserved (Massonnet et al. 2013; Mathiot et al. 2012). This implies that the physical processes underlying any ice thickness changes cannot be examined. Also, the need to run an ensemble of models limits the resolution possible in each case; Massonnet et al. (2013) run 25 ensemble members at $2^{\circ}$ resolution.

The goal of this paper is to produce a high-resolution, free-running, observationally validated hindcast of trends in Antarctic sea ice thickness and volume. This study is complementary to those of Massonnet et al. (2013) and Zhang (2014); the results will not be quantitatively perfect but the use of a free-running (non-data assimilating) model ensures that thickness trends are the result of calibrated model physics, which we examine in temporal and spatial detail. We place particular emphasis on a detailed assessment of our model results against satellite observations of the mean fields of Antarctic ice concentration, drift, and thickness, and the trend fields of ice concentration and drift. This validation provides a clear view of the relative confidence in the hindcasted ice thickness trends in different regions and seasons.

\section{Methods}

We use revision c62r of the Massachusetts Institute of Technology general circulation model (MITgcm; http:// mitgcm.org) in a regional model of all oceans, sea ice, and ice shelves south of $30^{\circ} \mathrm{S}$. The ocean component solves the Boussinesq Navier-Stokes equations on a generalized curvilinear grid using an Arakawa C-grid finite-volume discretization and $z$ levels in the vertical (Marshall et al. 1997). All components use the same horizontal mesh, with a locally isotropic resolution of $0.25^{\circ}$ in longitude, producing approximately square cells ranging from $\sim 10 \mathrm{~km}$ on each side at $70^{\circ} \mathrm{S}$ to $\sim 18 \mathrm{~km}$ at $50^{\circ} \mathrm{S}$. The ocean component has 50 vertical levels ranging from $10-\mathrm{m}$ resolution over the top $100 \mathrm{~m}$ to $457 \mathrm{~m}$ in the layer beneath $5461 \mathrm{~m}$, though the steplike representation of seabed and iceshelf topography is alleviated by the use of partial cells (Adcroft et al. 1997). Horizontal diffusivity is parameterized following Gent and McWilliams (1990) with a variable diffusivity (Visbeck et al. 1996) (limited to maximum $300 \mathrm{~m}^{2} \mathrm{~s}^{-1}$ ) and slope clipping (Large et al. 1997). Horizontal viscosity is flow dependent (Leith 1996). Vertical mixing is parameterized according to the $K$-profile parameterization (KPP) scheme (Large et al. 1994), which combines representations of ocean internal mixing and the surface mixed layer, exerting a significant influence upon the sea ice. A fully nonlinear equation of state is used (McDougall et al. 2003).

The sea ice component (Losch et al. 2010) is also formulated on a $\mathrm{C}$ grid. In this study we use an elasticviscous-plastic procedure to solve for ice dynamics with an elliptic yield curve. Free-slip conditions are applied at boundaries, and ice stress is applied directly to the surface of the ocean. Ice thermodynamics are treated using the "zero layer" approach, employing a constant thermal conductivity and linear temperature profile within the ice (Semtner 1976). The model has only two prognostic ice classes (ice and water) but a linear distribution of seven thickness classes is used in the thermodynamic calculations. A prognostic snow layer floods into ice if depressed below sea level. Ice salinity is neglected entirely, which implies a slight overprediction of freshwater fluxes because sea ice is in reality slightly saline. All prognostic variables are transported using first-order 
upwind advection. Far more sophisticated physical treatments of ice processes are available (Hunke and Lipscomb 2010), and it would be instructive to examine the effect of those in a future study, but the sea ice model is demonstrably able to reproduce the relevant ice observations (see below), so we are confident that its features are sufficient to support the conclusions of this study.

Initial conditions for ocean temperature and salinity are taken from the World Ocean Atlas (Boyer et al. 2009) (extrapolating southward where required) and seabed and ice-shelf topography is taken from the global 1' Refined Topography (RTOPO) dataset (Timmermann et al. 2010). Steady climatological boundary conditions are applied at $30^{\circ} \mathrm{S}$, with temperature and salinity taken from the World Ocean Atlas and ocean velocities taken from the second phase of the Estimating the Circulation and Climate of the Earth (ECCO2) reanalysis (Menemenlis et al. 2005). The ocean and sea ice surfaces are forced using 6-hourly fields from the European Centre for Medium-Range Weather Forecasts (ECMWF) Interim Re-Analysis (ERA-Interim; Dee et al. 2011) at a resolution of $1.5^{\circ}$ in both longitude and latitude. The forcing variables consist of zonal and meridional 10-m winds, 2-m air temperature and specific humidity, downward shortwave and longwave radiation, air pressure loading, and precipitation. The pressure loading and thermodynamic interactions of steady ice shelves are also included (Losch 2008). Iceberg melting is a significant source of freshwater to the Southern Ocean that occurs in a heterogeneous pattern depending upon the distribution of the bergs. We experimented with deriving this flux from third-party model fields, but these were completely dependent upon the modeled bergs and could never be truly representative of the time period used. Therefore, iceberg melting was represented simply by distributing a freshwater flux of $2000 \mathrm{Gt} \mathrm{yr}^{-1}$ uniformly around the coast (Jacobs et al. 1992). No ocean salinity restoring is used.

The paucity of in situ atmospheric data over the Southern Ocean means that reanalysis forcing data contain significant biases prior to the onset of satellite sounding data assimilation in late 1978 (Bromwich and Fogt 2004). Therefore, the model is first spun up by repeating 1980 forcings 10 times, and then run forward from 1981 to the end of 2011. Starting the simulations in January avoids the need for any initial sea ice distribution. Validation of the model against observed ice trends is essential to impart confidence in the modeled ice thickness trends, so we analyze only the period 1992-2010, for which reliable data of trends in ice concentration and drift are available (Holland and Kwok 2012). This provides a total of $22 \mathrm{yr}$ of model spinup time, and we are confident that the trends presented are the result of the atmospheric forcing, not ocean adjustment from initial conditions. In particular, a test simulation in which the 1980 forcings were repeated for $40 \mathrm{yr}$ shows no significant sea ice trends after year 20 .

The model validation requires observations of ice variables on an Antarctic-wide scale. Such observations do not exist directly, but can be derived from quantities observable by satellite. Daily ice concentration data generated from passive microwave emissions using the bootstrap algorithm are used, with all values below 0.15 masked (Comiso 2000). Ice drift data generated by feature tracking in the same passive microwave data are also available daily for the entire period, though only from April to October because of a high rejection rate of data in the Austral summer (Holland and Kwok 2012; Kwok et al. 1998). The only comprehensive ice thickness data available on the Antarctic-wide scale are from the Ice, Cloud, and Land Elevation Satellite (ICESat) laser altimetry campaigns, covering from one to three 1-month-long periods per year for 2003-08 (Kurtz and Markus 2012). These ice- and snow-thickness data are derived from measurements of freeboard and the assumption that the snow-ice interface is at sea level (i.e., all freeboard is snow and all draft is solid ice). This assumption is highly questionable in detail, but appears to provide a reasonable level of agreement with in situ observations overall (Kurtz and Markus 2012; Ozsoy-Cicek et al. 2013; Worby et al. 2008).

Various definitions of ice thickness are used in the literature. Throughout this study, effective ice thickness is defined as the volume of ice per unit area of ocean, which is the quantity conserved by the model, while average ice thickness is used to refer to the volume of ice per unit area of ice, which is closer to the quantity measured in the field. Effective ice thickness is the product of the average ice thickness and the ice area concentration. We generally investigate fields of effective ice thickness because that is the quantity most relevant to the overall changes in ice volume, but the Antarctic-wide average ice thickness is also examined. We consider the thickness of ice only, rather than including the iceborne snow layer, because the ice component is of greater interest to many scientific questions and is also better constrained in our model, which uses uncertain reanalysis precipitation fields to generate iceborne snow. We consider seasonal maps of means and trends calculated from monthly-mean model output. Mean fields for each season are the overall average of all appropriate months from all years. To produce trend fields, for each grid point we first convert the model output into a time series of season-mean values, and then calculate the interannual trend for each season from the appropriate seasonal values over the different years. For example, to calculate the trend in winter ice concentration, we create fields of the mean ice concentration for 
each winter and then plot, at each grid point, the interannual trends in those fields.

\section{Results}

Before examining our results it is worth considering the extent to which we would expect real ice thickness trends to be represented in a free-running hindcast model. In any model forced by atmospheric reanalyses, ice extent (the ocean area covered by an ice concentration of at least 0.15 ) should be well captured; reanalysis models use observed ice concentration in their surface boundary condition, so the ice is imprinted onto their near-surface fields and then recreated in the forced ocean model. However, hindcasting ice area (the area integral of ice concentration) and thickness, hence volume, is more challenging. Antarctic ice drift is dominated by surface winds, and ERA-Interim is known to capture the appropriate wind trends (Holland and Kwok 2012). ERA-Interim air temperatures (Bracegirdle and Marshall 2012) and our model ocean temperatures (see below) are also reasonable, implying little limitation on the ice hindcast. However, ice concentration and (crucially) thickness are strongly affected by snow cover (Powell et al. 2005) and ocean freshwater fluxes (Hellmer 2004; Zhang 2007), both of which are limited by the large uncertainty in reanalysis precipitation fields [although ERA-Interim is among the best, according to Bromwich et al. (2011)]. Also, any convergence-driven dynamical ice thickening will be determined by the assumed rheology of the ice, of which model treatments are uncertain (Feltham 2008; Tsamados et al. 2013). We, therefore, expect modeled ice thickness trends to be affected by poorly constrained details of the forcing and models. As a result, we perform a qualitative assessment of our model results against existing observations, and consider broad patterns of ice thickness change rather than quantitative predictions for specific regions, which are perhaps better provided by the dataassimilating model of Massonnet et al. (2013).

\section{a. Modeled ocean mean state}

Since the ocean state and trends can potentially have a significant effect on sea ice, we first assess the mean state of our modeled ocean over the period of interest, 19922010 (Fig. 1). The long-term mean barotropic streamfunction of the model (Fig. 1a) reproduces the observed path of the Antarctic Circumpolar Current (ACC; Orsi et al. 1995; Sokolov and Rintoul 2009) and, crucially, also captures the shape and strength of the subpolar Weddell and Ross Gyres (Wang and Meredith 2008). Thus, to the extent permitted by the sparse available data, we can have some confidence that the dynamic coupling between ocean and ice is accurate.
The thermodynamic interaction is harder to verify, since there are very few relevant observations of the ocean beneath Antarctic sea ice. Most of our knowledge of ice-ocean interaction comes from summertime observations of the remnant winter water and shelf waters formed by winter sea ice production. As summarized by Petty et al. (2013), these observations show that in the Weddell and Ross Seas the surface mixed layer extends to the seabed in winter, filling the shelf seas with cold and saline shelf waters, while in the Amundsen and Bellingshausen Seas the winter mixing only produces a shallower layer of Winter Water, beneath which warmer Circumpolar Deep Water is allowed to persist on the shelf. The mean winter mixed layer depth (Fig. 1b) predicted by the KPP scheme (defined as the shallowest depth for which the overlying bulk Richardson number equals 0.3 ) shows that the model is able to reproduce these features, with complete destratification in the Weddell and Ross Seas and progressively shallower convection in the Amundsen and Bellingshausen Seas. This is also reflected in the long-term mean temperature and salinity at the seabed, which shows warm and relatively fresh Circumpolar Deep Water in the Amundsen and Bellingshausen Seas and cold and saline shelf waters in the Weddell and Ross Seas (Figs. 1c and 1d). Farther offshore, the winter mixed layer shallows over the sea ice zone due to a reduction in surface stress and buoyancy forcing, and then deepens offshore of the ice edge. Thus, the vertical structure of the water column seems to compare well to the limited observations that exist, and we infer that the thermodynamic ice-ocean interaction is reasonable as far as it can be tested.

\section{b. Modeled ice mean state}

We next compare the mean state of our modeled Antarctic sea ice to observations over the period of interest, 1992-2010. A comparison of mean ice concentration by season (Fig. 2) shows that the modeled ice concentration in austral autumn and winter are very good, which is critical because these seasons have the largest observed ice concentration trends (Turner et al. 2009) and are best covered by ice motion data. Concentrations in spring and summer are not as good, with two persistent problems. First, the model fails to capture a "halo" of low ice concentration near $0^{\circ}$ in spring (Lindsay et al. 2004), which leads to excessive summer ice concentration in the eastern Weddell Sea. The halo is thought to be caused by upward deformation of warm isopycnals near the Maud Rise seamount (de Steur et al. 2007), which is a challenging feature to accurately capture in a large-scale $z$-level ocean model. Attempts were made to produce this feature using a variety of ocean mixing schemes, but these resulted in open-ocean convection and a large polynya in the region (Timmermann 

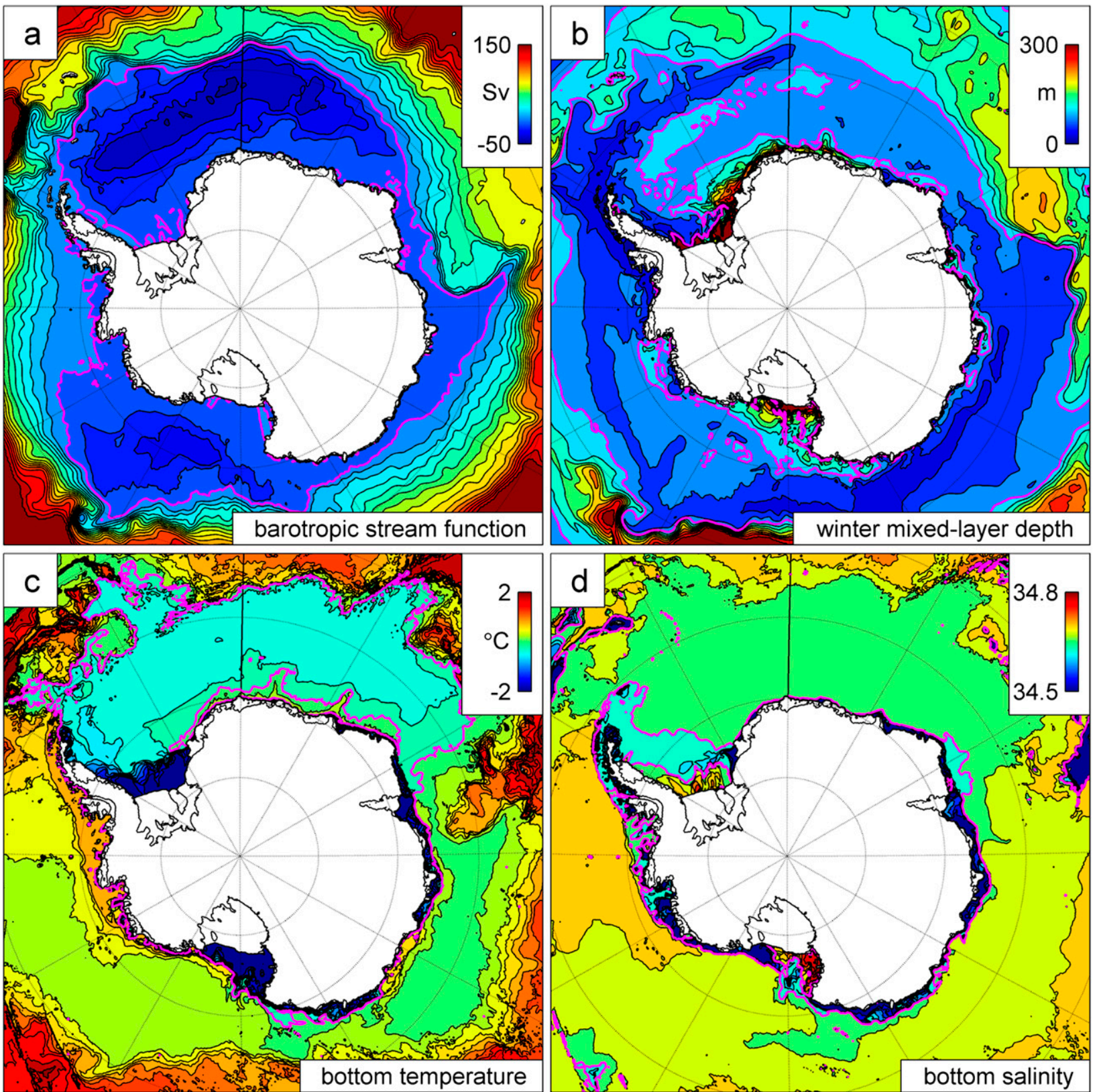

FIG. 1. Modeled mean 1992-2010 ocean fields: (a) barotropic streamfunction [contours every $10 \mathrm{~Sv}$, magenta contour $=0 \mathrm{~Sv}(1 \mathrm{~Sv} \equiv$ $10^{6} \mathrm{~m}^{3} \mathrm{~s}^{-1}$ ) ]; (b) winter [June-August (JJA)] mean mixed layer depth from KPP calculation (contours every $25 \mathrm{~m}$, magenta contour $=$ $100 \mathrm{~m}$ ); (c) potential temperature at seabed (contours every $0.2^{\circ} \mathrm{C}$, magenta contour $=0^{\circ} \mathrm{C}$ ); and $(\mathrm{d})$ salinity at seabed (contours every 0.025 , magenta contour $=34.65)$.

and Beckmann 2004), strongly degrading the agreement with observations. Second, low ice concentrations in the Ross Sea polynya are poorly represented in both spring and summer. Northward ice export in this region is reasonable (see below), so this problem is due to excessive importation of ice from the east.

A similar comparison of effective ice thickness (Fig. 3) shows reasonable results, although some ice concentration errors are also apparent in effective thickness. The model captures the general magnitude of ice thickness and correctly produces thicker ice in the Weddell, Bellingshausen, and Amundsen Seas, though the spatial patterns within each region are imperfect. The model underrepresents the thickest ice in the northwest corner of the Weddell Sea, though this problem is minimal in autumn, the season of greatest interest here. Ice is too 


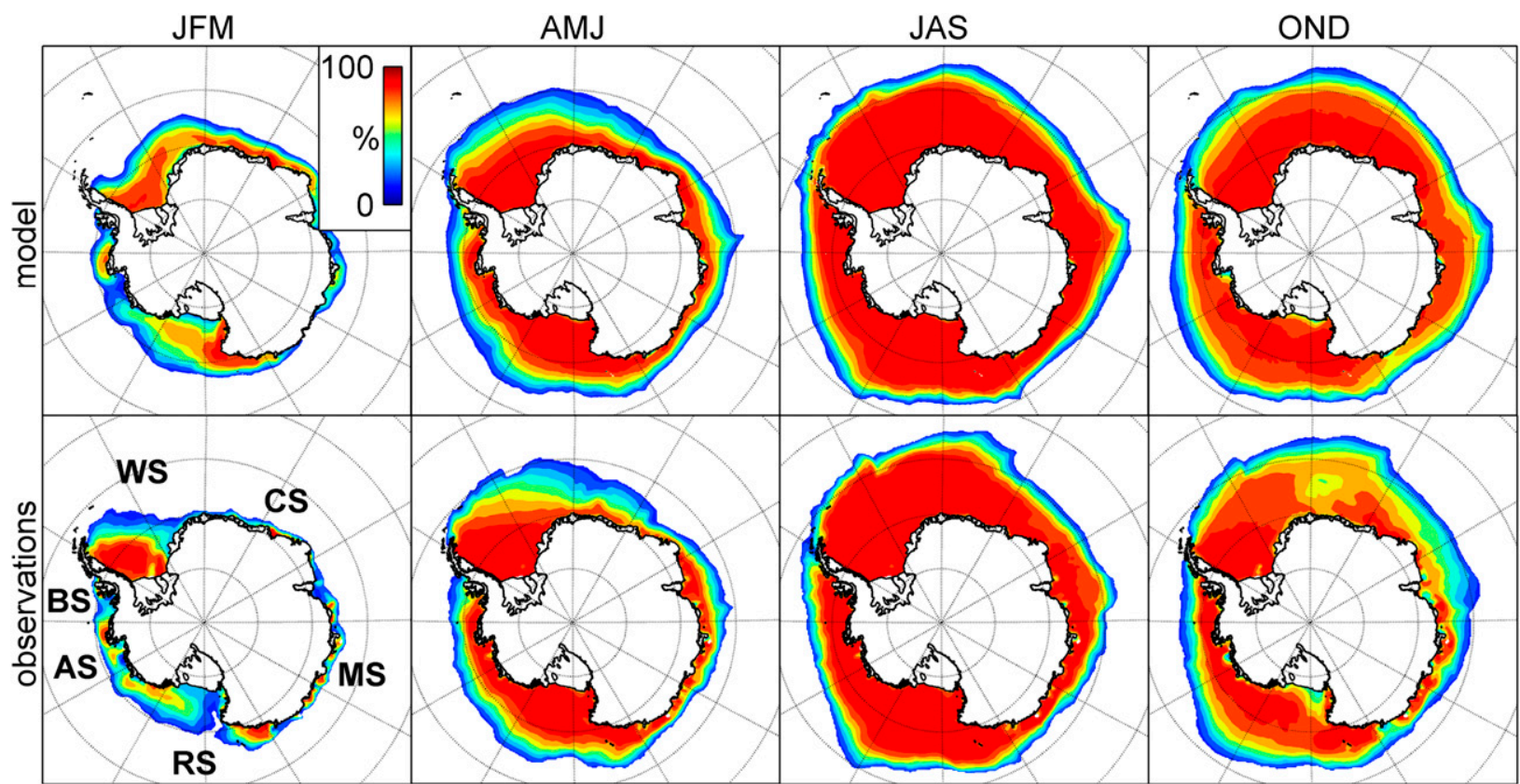

FIG. 2. (top) Modeled and (bottom) observed 1992-2010 mean ice concentration by (left)-(right) season. Observed ice concentration is calculated using the bootstrap algorithm (Comiso 2000). The two-letter descriptors are Weddell Sea (WS), Cosmonaut Sea (CS), Mawson Sea (MS), Ross Sea (RS), Amundsen Sea (AS), and Bellingshausen Sea (BS).

thick in the eastern Weddell Sea, in accordance with the aforementioned lack of halo in this region, and the model overpredicts effective ice thickness in the Ross Sea polynya in all seasons. A similar validation of effective snow thickness (Fig. 4) is perhaps worse, with the model failing to reproduce the correct thicknesses in summer and autumn, and producing the wrong pattern in the Weddell Sea in spring. This is unsurprising given the uncertainty

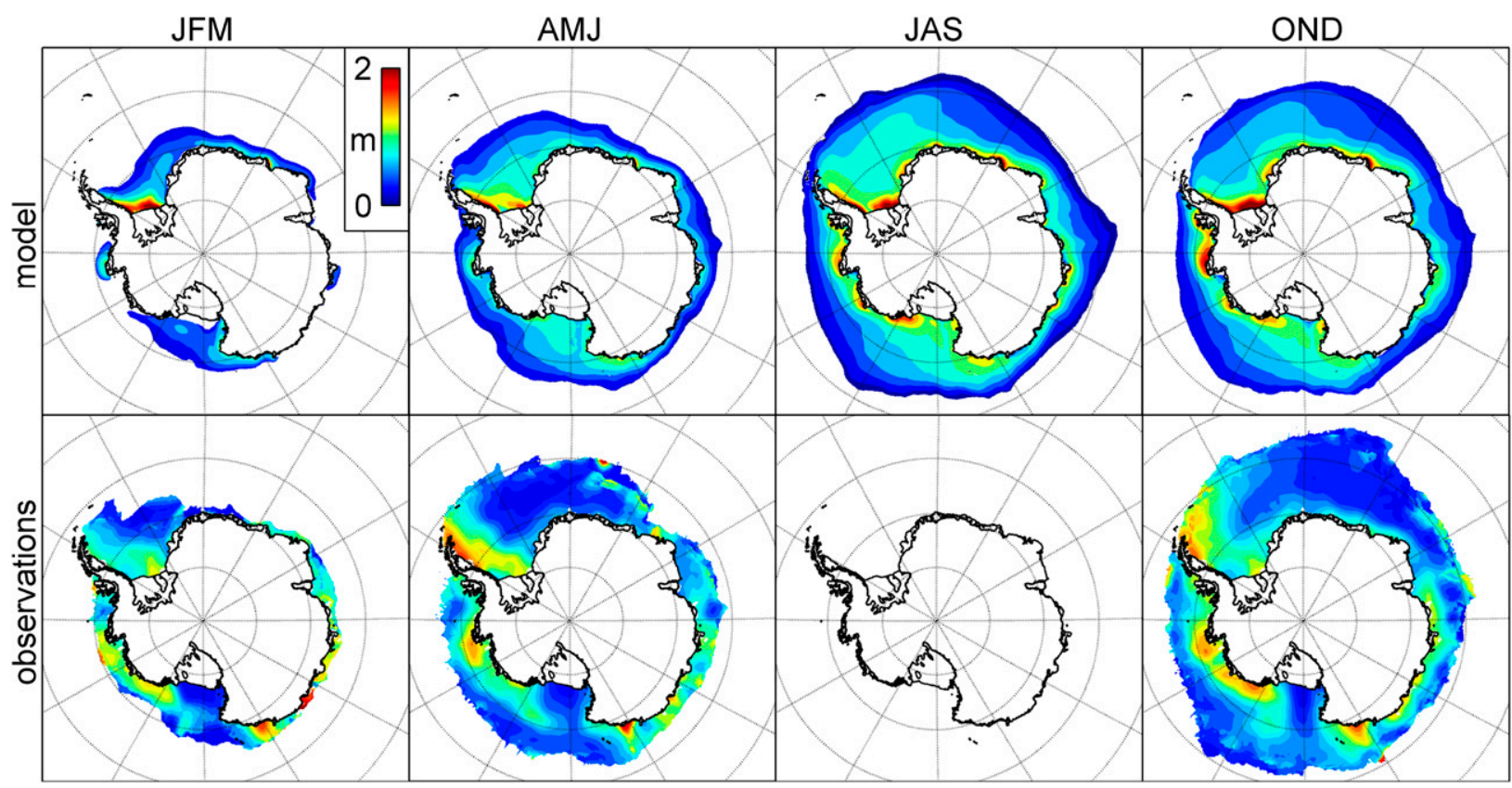

FIG. 3. (top) Modeled mean 1992-2010 effective ice thickness and (bottom) observed mean 2003-08 effective ice thickness by (left)(right) season. Effective ice thickness is defined as volume of ice per unit area of ocean, neglecting the iceborne snow layer. Observed effective ice thickness is derived from ICESat measurements (Kurtz and Markus 2012). Areas with respective ice concentration $<0.5$ are masked in both datasets. 


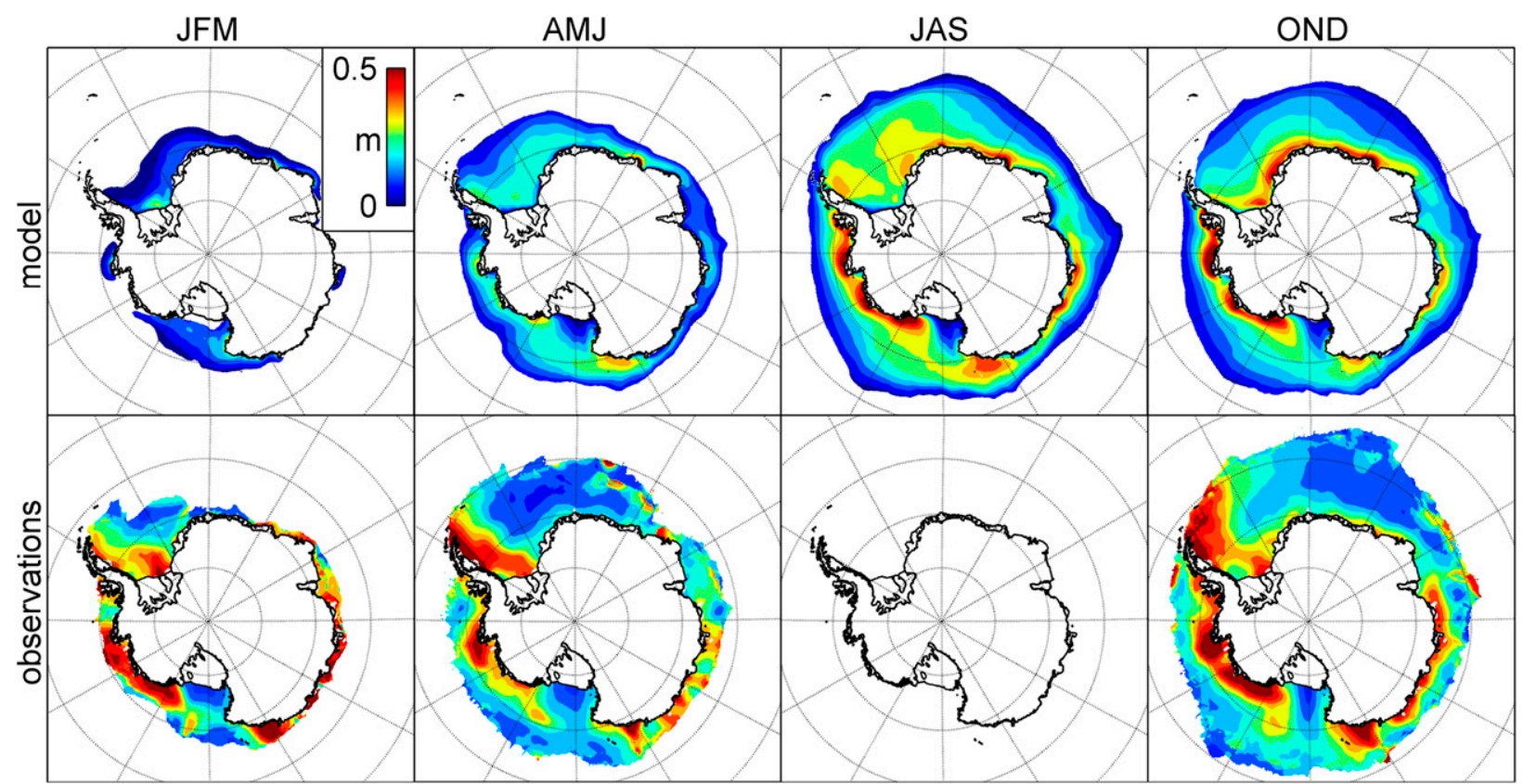

FIG. 4. As in Fig. 3, but for snow. Effective snow thickness is defined as volume of iceborne snow per unit area of ocean.

surrounding reanalysis precipitation fields, but does place a limitation on our results because snow flooding is an important component of Antarctic sea ice growth (Powell et al. 2005). The model produces a relatively good representation of effective snow thickness in the Pacific sector in spring.

Given the model's better performance in autumn and winter, and the larger ice trends and greater availability of data in those seasons, the rest of this study concentrates primarily on those seasons. Figure 5 shows the mean ice velocities predicted by the model, which agree with the observations rather well. The focused northward ice export from the Ross Sea and widespread export in the Weddell Sea are reproduced well, as is the westward coastal current around East Antarctica. Ice drift is a little too rapid near coastlines and the ice edge. This may be a feature of the coarse sampling of the ice observations in these regions, but is more likely to be inaccuracy in the modeled ice dynamics (Uotila et al. 2013, manuscript submitted to Ocean Modell.). Near the coast this could be caused by problems with the coarse wind forcing or ice rheology. The overzealous coastal current in the Pacific sector transports too much ice from the Bellingshausen and Amundsen Seas into the Ross Sea, explaining the excessive ice concentration in the latter.

The modeled seasonal cycle in total Antarctic ice area (the area integral of ice concentration) compares extremely well with observations (Fig. 6a), which is an important result because ice area is much harder to reproduce in a model than ice extent. The mean cycle of total Antarctic ice volume (Fig. 6b) is also in excellent agreement with the data that exist. The modeled Antarctic-wide average ice thickness (total ice volume divided by total ice area; Fig. 6b) is remarkably constant throughout the year, varying by less than $20 \%$. This implies that autumn-winter ice thickening is offset by the growth of large areas of thin ice, and spring/summer ice thinning is offset by the melting of large areas of thin ice. The observations suggest the possibility that thicker ice in summer is missed by the model, but this is uncertain because the observations are derived with different assumed values for snow density in each season. If a uniform snow density were used for all seasons, the derived ice thickness would be larger in spring and smaller in summer, in closer agreement with the model.

\section{c. Modeled ice trends}

Figure 6 also provides an overview of modeled and observed trends in Antarctic sea ice. Monthly anomalies of ice area from the mean seasonal cycle for the respective datasets are remarkably consistent between model and observations (Fig. 6c), with a few exceptions, leading to a good prediction of the overall magnitude of the area trend. Given the difficulty inherent in hindcasting ice area, this is an encouraging result that leads to some confidence in the modeled trends. Building on this confidence, Fig. 6d shows a primary conclusion of this model study, that overall Antarctic ice volume and Antarcticwide average ice thickness have both increased over 1992-2010. The overall volume increase of $29 \mathrm{~km}^{3} \mathrm{yr}^{-1}$ is 


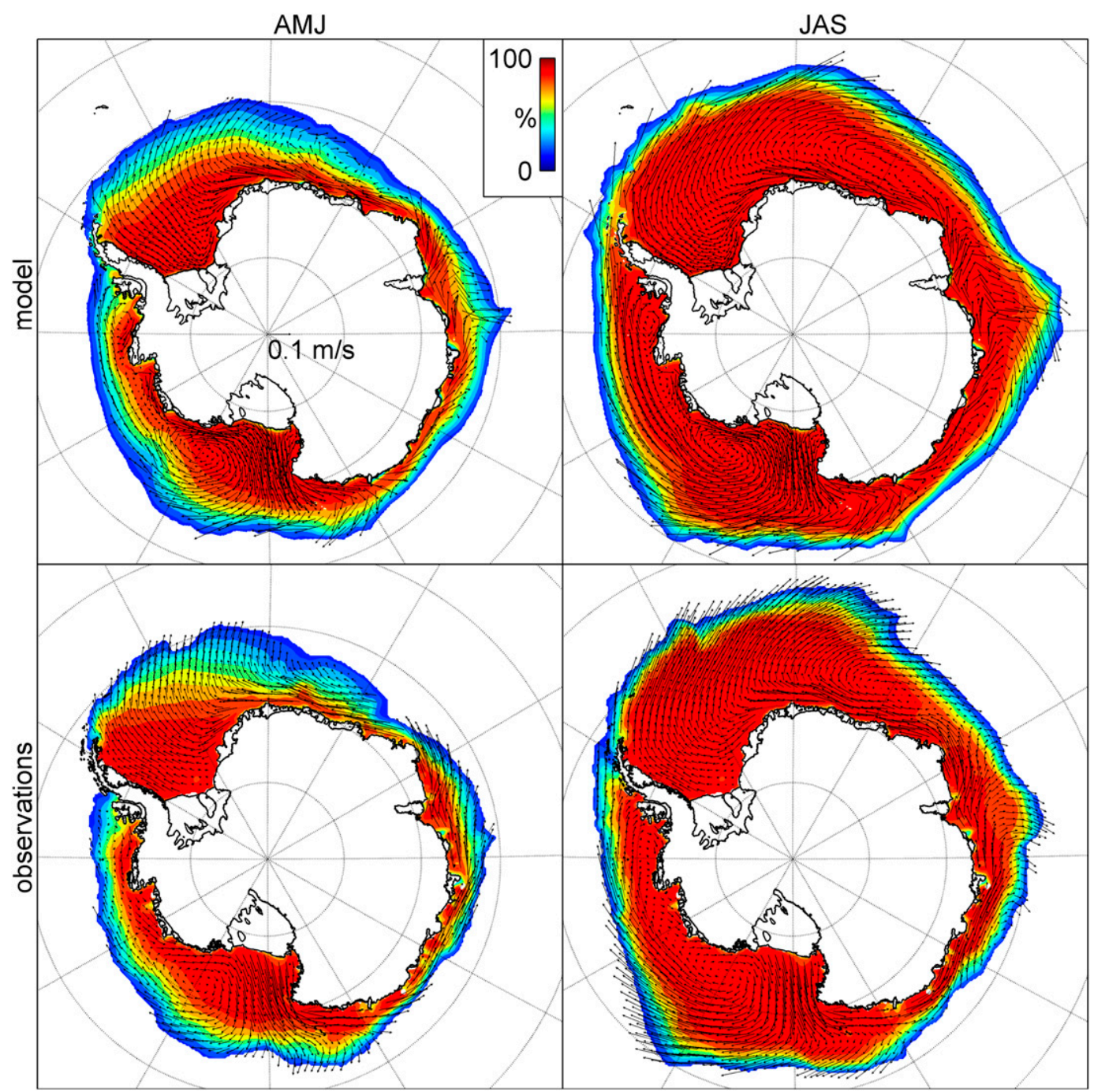

FIG. 5. (top) Modeled and (bottom) observed 1992-2010 mean ice concentration (\%, colors) and ice drift velocity (vectors with the reference vector of $0.1 \mathrm{~m} \mathrm{~s}^{-1}$ at center of top-left panel) for (left) autumn and (right) winter seasons. Observed ice concentration is calculated using the bootstrap algorithm (Comiso 2000) and ice velocities are from passive microwave feature tracking (Holland and Kwok 2012). Model velocities are shown every tenth grid point.

in good agreement with the central Massonnet et al. (2013) estimate of $36 \mathrm{~km}^{3} \mathrm{yr}^{-1}$ for $1980-2008$ using data assimilation. The ice volume anomaly time series largely follows that of ice area (Fig. 6c), but there are several occasions where anomalies in average ice thickness contribute significantly to ice volume, such as in the prolonged negative anomaly in both variables between 2002 and 2004. As fractions of their mean annual values, the increases in Antarctic average ice thickness $\left(1.5 \mathrm{~mm} \mathrm{yr}^{-1}\right.$ / $\left.0.7 \mathrm{~m} \sim 0.2 \% \mathrm{yr}^{-1}\right)$ and total area $\left(20 \times 10^{3} \mathrm{~km}^{2} \mathrm{yr}^{-1}\right.$ / $\left.10^{7} \mathrm{~km}^{2} \sim 0.2 \% \mathrm{yr}^{-1}\right)$ contribute equally to the trend in ice volume $\left(30 \mathrm{~km}^{3} \mathrm{yr}^{-1} / 7 \times 10^{3} \mathrm{~km}^{3} \sim 0.4 \% \mathrm{yr}^{-1}\right)$. The Antarctic average ice thickness trend produces a feasible increase of $2.6 \mathrm{~cm}$ over the period considered. It is noteworthy that the simulation of Zhang (2014) produces a similar fractional trend in ice volume $\left(0.46 \% \mathrm{yr}^{-1}\right)$ despite having ice that is approximately double the observed thickness; this suggests that the Zhang (2014) thickness and volume trends are approximately twice the real value (since the extent trend is accurate in that study).

These overall time series hide a strong pattern of regional variation in the trends, much of which compensates, so that the overall Antarctic-mean trends are the residual of much larger regional changes. Figure $7 \mathrm{com}-$ pares, by season, the maps of linear trend in modeled and observed ice concentration. The general agreement is exceptionally good, with the model clearly reproducing the wavelike pattern of ice concentration trends during 

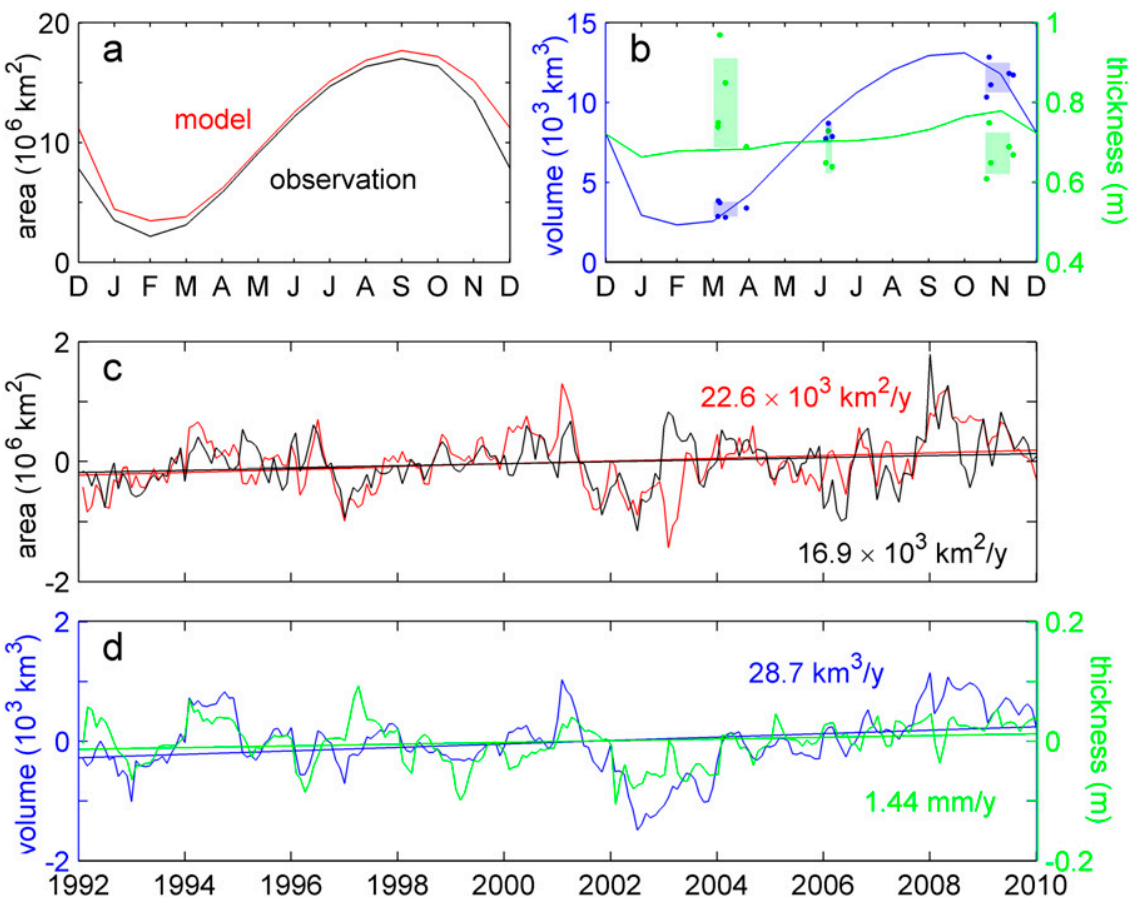

FIG. 6. The 1992-2010 temporal variability of total Antarctic sea ice variables from model (gray lines) and observation (black lines). (a) Mean seasonal cycle in total ice area (the area integral of ice concentration) (Comiso 2000). (b) Mean seasonal cycle in total ice volume and mean ice thickness (total ice volume divided by total ice area) with dots representing individual ICESat campaigns and shaded areas representing the interannual mean \pm 1 standard deviation for each season; Kurtz and Markus (2012). (c) Monthly anomalies in total ice area from the respective climatologies in (a). (d) Monthly anomalies in modeled total ice volume and mean ice thickness from the respective climatologies in (b). All trends shown [straight lines in (c) and (d)] are significant at the $99 \%$ level.

this period: decreasing ice cover in Bellingshausen, Weddell, and Mawson Seas, and increasing ice cover in Ross, Amundsen, and Cosmonaut Seas (Holland and Kwok 2012). The model trends are least reliable in summer, which is unsurprising given the above validation of mean ice concentration in this season. It is interesting to note that the modeled concentration trends seem to be shifted eastward relative to the observed trends. We are unsure why this is, but speculate that the reanalysis winds place the climatological lows in the circumpolar pressure trough (and thus their trends) too far east as a result of poorly representing the deepening of low pressure systems as they navigate Antarctic topography.

We again restrict our attention to autumn and winter, and investigate the agreement of trends in ice drift between model and observations (Fig. 8). Since ice thickness is strongly affected by convergence and divergence, it is essential to have confidence in our modeled ice-drift trends if we are to believe our modeled thickness trends. As shown in Fig. 8, the dynamical trends in autumn are in good agreement with observations, particularly considering how challenging it is to correctly model ice velocities, let alone their linear trend. This agreement is largely the result of accurate surface wind trends in ERA-Interim (Holland and Kwok 2012). In autumn the model correctly produces the observed decadal increase in northward ice export in the Ross, Amundsen, and Cosmonaut Seas, and the observed decrease in northward export in the Weddell and Mawson Seas (Holland and Kwok 2012). Wind and ice-dynamical trends in winter do not fit the observations quite as well, but the broad features of a southward trend in the Bellingshausen Sea and northward trend around $0^{\circ}$ are found in both model and observations.

These observational assessments of modeled trends in ice concentration and velocity allow us to critically consider the pattern of trends in effective ice thickness (Fig. 9) that cause the overall increase in Antarctic sea ice volume. It is immediately apparent that the regional trends in effective ice thickness are at least an order of magnitude larger than the Antarctic-mean trend (Fig. 6), which is their residual. The largest effective thickness trends (up to $5 \mathrm{~cm} \mathrm{yr}^{-1}$ ) are found in the Amundsen Sea in winter. This further demonstrates that, while overall 


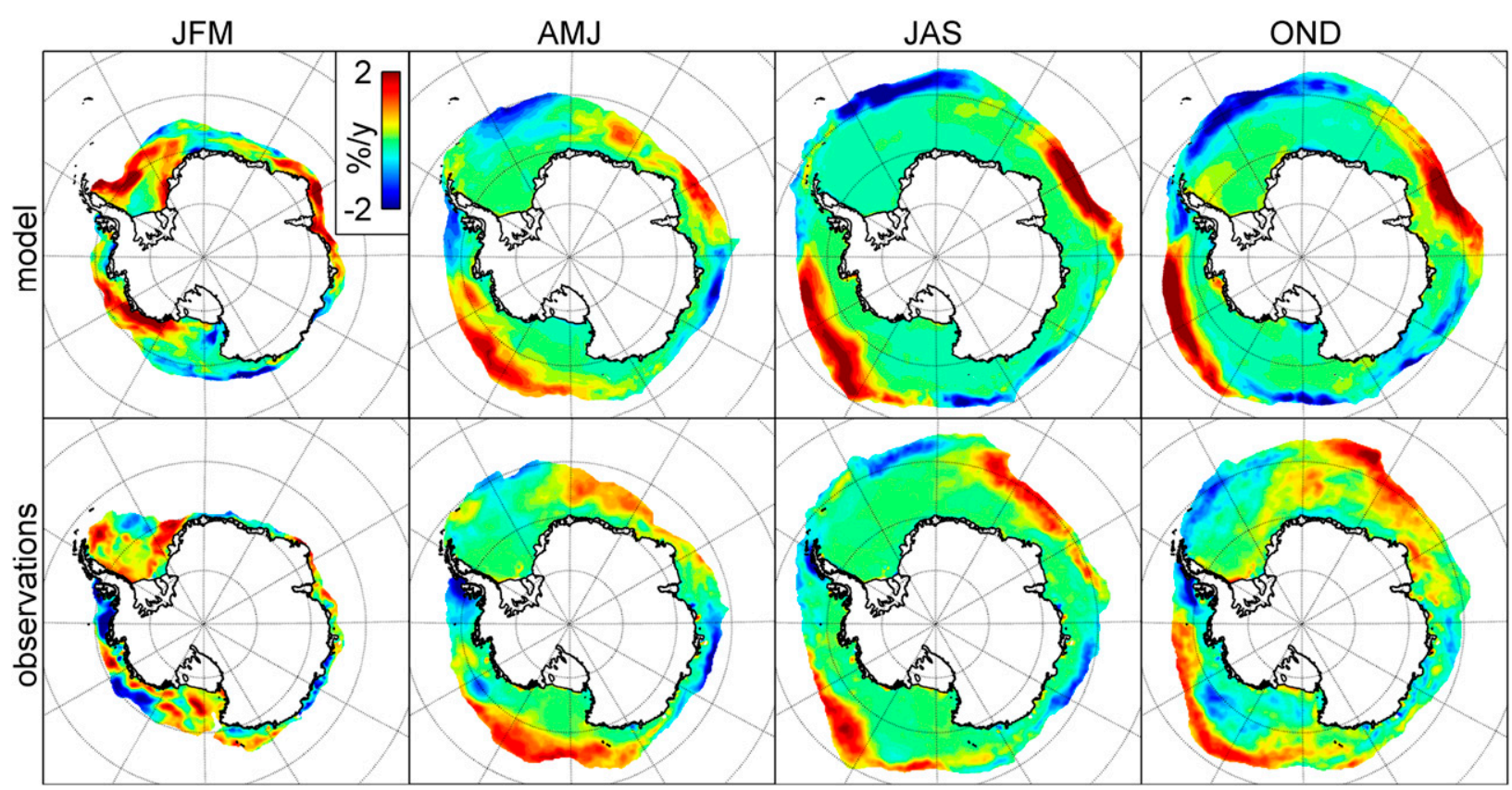

FIG. 7. (top) Modeled and (bottom) observed 1992-2010 linear trends in ice concentration by (left)-(right) season. Observed ice concentration is calculated using the bootstrap algorithm (Comiso 2000).

Antarctic ice trends may be subtle, the local changes can be of a considerable magnitude. Unsurprisingly, we find that around the ice edge the spatial distribution of effective ice thickness trends (Fig. 9) mimics the trends in ice concentration (Fig. 8), although there are differences in the relative magnitude of these trends. More importantly, the model also produces effective ice thickness trends in the internal ice pack near the coast, which are not apparent in the concentration trends because the ice is close to full cover throughout the periods considered. These "internal" thickness trends have the largest regional magnitudes, and are an important finding of this study. There are three main regions of internal ice thickness increase: the northwest Weddell Sea in autumn, southern Weddell Sea in autumn and winter, and the Amundsen and Bellingshausen Seas in winter. Similar trends appear in the model results of Massonnet et al. (2013) and Zhang (2014), though their seasonal structure and physical origin have not been fully examined.

It is important to note that the maps of trend in effective ice thickness (volume ice per area of ocean) are nearly identical to maps of trend in average ice thickness (volume ice per area ice). Away from the ice edge, the concentration remains near full cover throughout, so the effective and average thickness are practically the same. Near the ice edge the average ice thickness is of order $10 \mathrm{~cm}$, so the observed changes in ice concentration alone, of order $1 \% \mathrm{yr}^{-1}$, would give a change in effective ice thickness of order $1 \mathrm{~mm} \mathrm{yr}^{-1}$. This is negligible compared to the modeled effective ice thickness changes of order $1 \mathrm{~cm} \mathrm{yr}^{-1}$, which are therefore demonstrated to be the result of large changes in average ice thickness. In other words, the trends in effective ice thickness (volume ice per area of ocean) near the ice edge in Fig. 9 are negligibly affected by the trends in ice concentration (area ice per area ocean) in Fig. 8; they are instead almost entirely trends in average ice thickness (volume ice per area ice). To investigate these trends further we now consider a diagnostic decomposition of the ice-thickness equation.

\section{d. Analysis of ice trends}

An overview of the processes governing the evolution of effective ice thickness can be obtained by separating the total tendency of effective thickness into dynamic and thermodynamic parts. Effective thickness is governed by a simple conservation equation:

$$
\frac{\partial h}{\partial t}=-\nabla \cdot(\mathbf{u} h)+f
$$

where $h$ is effective thickness and $\mathbf{u}$ is velocity. The first term on the right-hand side is the thickness change caused by ice-flux divergence, as determined by the momentum balance, while $f$ is the change in thickness due to thermodynamic processes. We record the values of each of these terms separately, and the total tendency, in the ice code. Examination of the mean fields of these tendency terms is highly instructive, as shown in an observational 


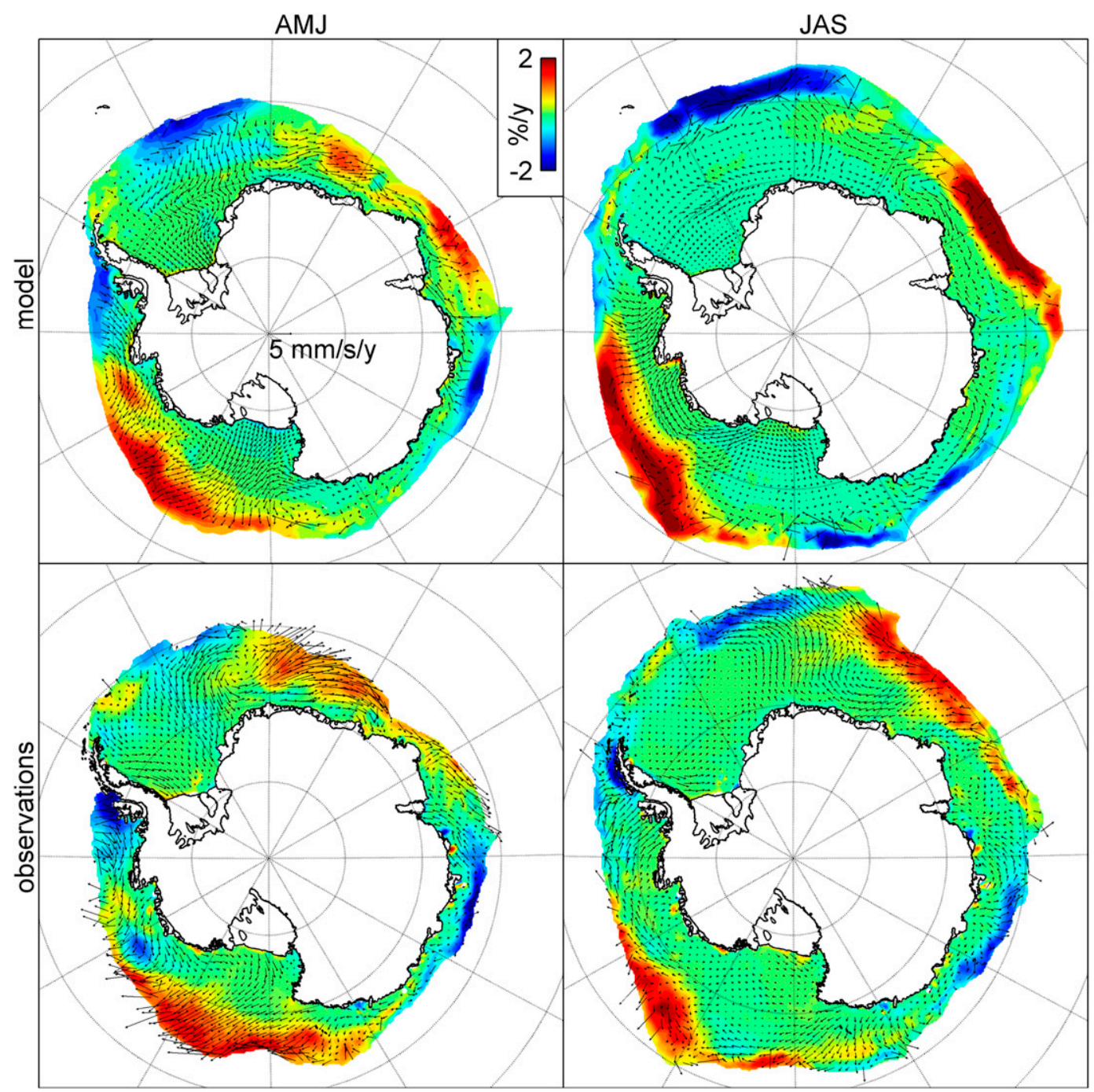

FIG. 8. As in Fig. 5, but for linear trends in ice concentration $\left(\% \mathrm{yr}^{-1}\right.$, colors) and drift velocity (reference vector of $\left.5 \mathrm{~mm} \mathrm{~s}^{-1} \mathrm{yr}^{-1}\right)$.

assessment by Holland and Kwok (2012), but here our purpose is to assess trends in ice thickness, for which we assess trends in the tendency terms. This analysis is performed for autumn and winter only, the seasons for which we have the greatest confidence in the model results.

As with all such calculations, maps of interannual trend in the tendency terms are generated by constructing seasonal means of the terms at each grid point and then calculating the interannual trend in the values for each season. The tendency terms represent the rate of change of effective ice thickness during a particular season, so our calculated trends represent the change in that rate over the decadal time period considered. For this reason, the trends in effective ice thickness (e.g., Fig. 10a) do not exactly match trends in effective ice thickness tendency (e.g., Fig. 10b). The former is the trend in mean autumn effective ice thickness, while the latter is the trend in the mean change in effective ice thickness over autumn. For example, some of the trends in autumn ice thickness are caused by thicker ice being present at the end of summer, and this would cause the two quantities to disagree. However, trends in the autumn effective thickness tendency (Fig. 10b) do explain many of the features in the autumn effective thickness trend map (Fig. 10a). The only significant regions of disagreement are the areas of ice thickness increase in the southern Amundsen and Ross Seas and northwest Weddell Sea, which are therefore revealed to be the result of summertime trends. The model performance is imperfect in summer, so these features should be treated with caution.

The majority of the trends in effective ice thickness (Fig. 10a) are reflected in the trends in effective thickness 


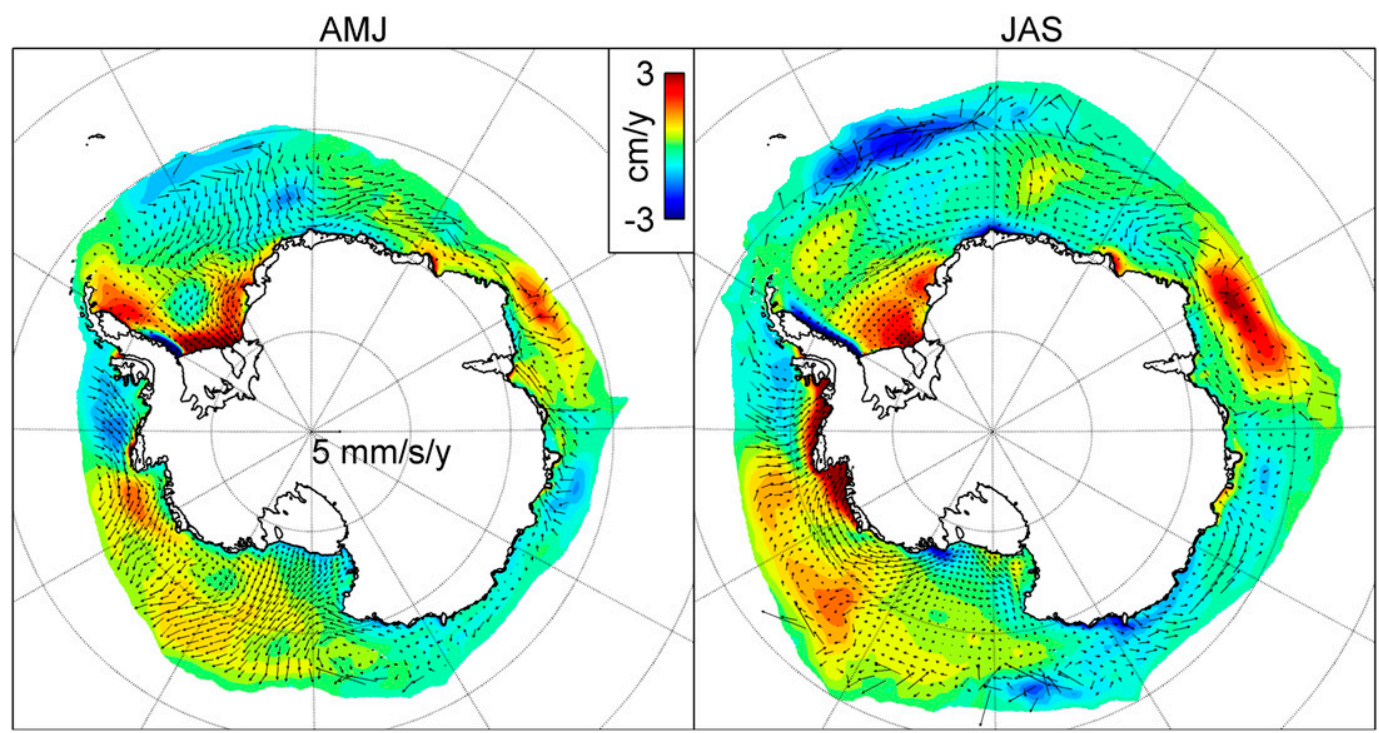

FIG. 9. Modeled 1992-2010 linear trends in effective ice thickness $\left(\mathrm{cm} \mathrm{yr}^{-1}\right.$, colors) and ice drift velocity (vectors with the reference vector of $5 \mathrm{~mm} \mathrm{~s}^{-1} \mathrm{yr}^{-1}$ at center of left panel) for (left) autumn and (right) winter seasons. Effective ice thickness is defined as volume of ice per unit area of ocean, neglecting the iceborne snow layer. Model velocities are shown every tenth grid point. The largest trends, up to $5 \mathrm{~cm} \mathrm{yr}^{-1}$, are in the Amundsen Sea in winter.

tendency (Fig. 10b), which we can decompose exactly into dynamic (Fig. 10c) and thermodynamic (Fig. 10d) parts. This decomposition reveals that the trends in the Pacific sector are mostly explained by changes in ice dynamics (cf. Figs. 10b,c). The autumn thickness trend in the southern Weddell Sea is also caused by dynamics, but the thinning in the northern Weddell Sea, and most of the changes around East Antarctica, are due to thermodynamic changes. Changes in wind stress (Fig. 10a) succinctly explain all of these changes. In the Amundsen and Ross Seas, increased northward ice transport in autumn causes thinning in the south and thickening in the north. In the Bellingshausen Sea, a southward trend in wind stress causes the exact opposite, a loss of ice from the ice edge, and a strong thickening near the coast. In the Weddell Sea a decrease in northward ice export away from the coast causes strong thickening. The thermodynamic ice loss to the north could be a result of the decreased export of cold and dry air from Antarctica, or perhaps a southward shift of the warmer waters of the ACC, either of which could be caused by the wind trends. The remaining trends all follow the same pattern of increased (decreased) northward wind stress causing ice thickness increase (decrease) near the ice edge, through a varying combination of changes in air-ice drag and cold- or warm-air advection. These results are in complete agreement with the analysis of Holland and Kwok (2012), who used observations to perform an autumn decomposition of the conservation equation for ice concentration. Wind-driven ice convergence and a resultant thickening in the Pacific sector and southern
Weddell Sea were also obtained by Zhang (2014). Finally, we note that the decomposition suggests an increased ice divergence and thermodynamic ice growth in the Ross Sea coastal polynya (Figs. 10c,d), and a decrease in divergence and growth in the Ronne polynya, Weddell Sea, both in agreement with observed trends (Drucker et al. 2011).

The results in winter (Fig. 11) illustrate the difference between trends in effective ice thickness and effective ice thickness tendency. In this season few of the large ice thickness trends (Fig. 11a) are observed in the tendency terms (Fig. 11b), implying that the thickness trends are the result of changes occurring in previous seasons. For example, the ice thinning trend in the northern Weddell Sea (Fig. 11a) is revealed as being a lasting effect of previous seasons; the trend in winter tendency (Fig. 11b) is toward thickening. On average, there is thinner ice in the northern Weddell Sea during winter, but this ice is thickening more during winter. The ice is thickening less during autumn, and the ice remains thinner during winter as a result. The increased thickening during winter is revealed as being dynamical in origin (Fig. 11c), because the wind trend in this region is toward increased northward flow (Fig. 11a).

Some effective thickness trends that are very clearly caused by wintertime changes are in the Bellingshausen and Amundsen Seas, where strong wind trends toward the south lead to a significant winter thickening of the ice near the coast that is entirely dynamic in origin (Fig. 11). It is virtually certain that these thickening trends have occurred in reality, since they are the logical extension 


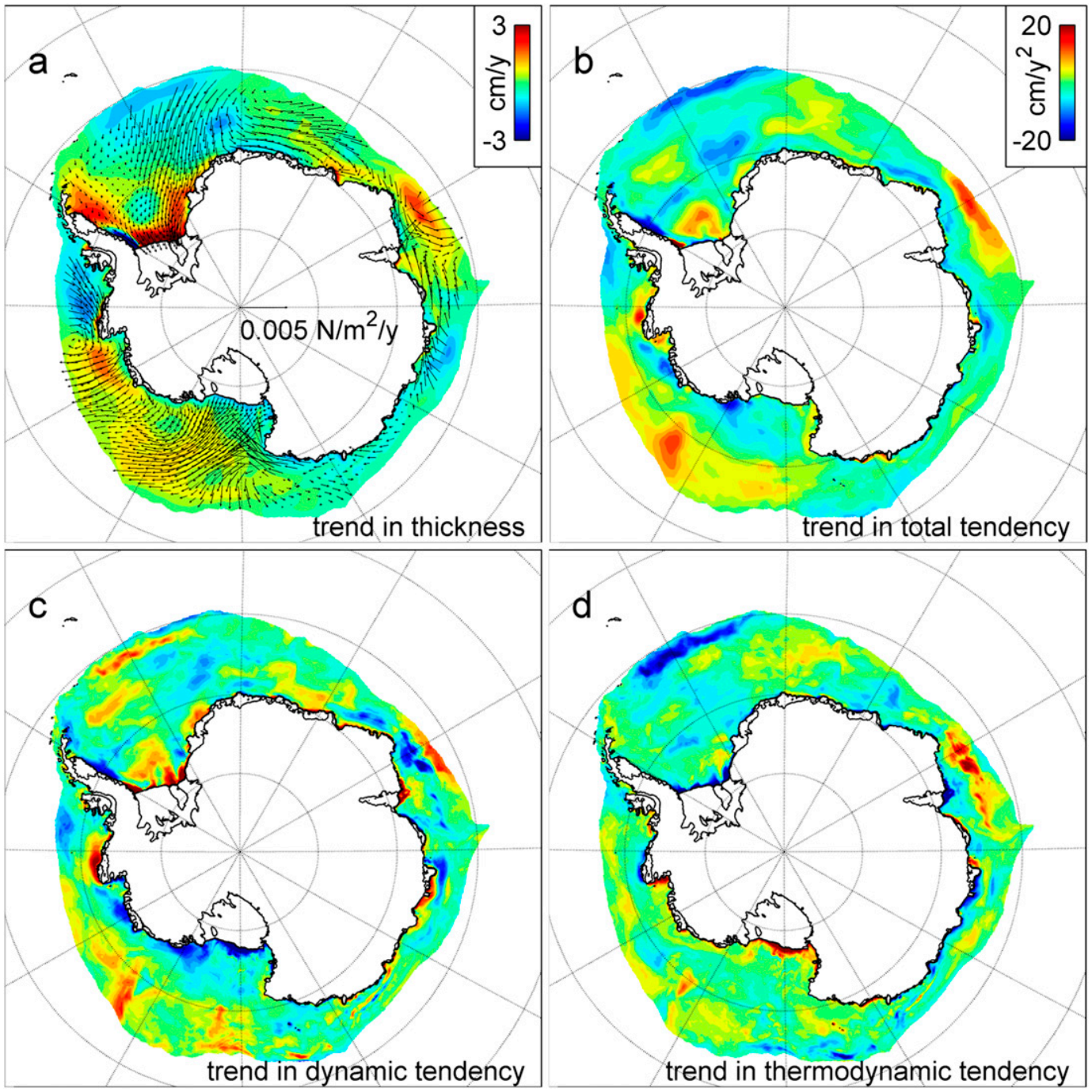

FIG. 10. Modeled autumn [April-June (AMJ)] 1992-2010 linear trends in effective ice thickness and related quantities. (a) Modeled effective ice thickness and ERA-Interim wind stress (vectors shown every tenth grid point with reference vector of $0.005 \mathrm{~N} \mathrm{~m}^{-2} \mathrm{yr}^{-1}$ ). (b)-(d) Ice-thickness equation terms: evolution, dynamic, and thermodynamic parts, respectively. The color bar for (c),(d) is as in (b).

of known trends in ice concentration, winds, and ice drift in this region (Holland and Kwok 2012; Turner et al. 2009). The model is clearly responding sensibly to the wind stress it receives from ERA-Interim (Fig. 11a). However the magnitude and pattern of this thickening must be regarded as merely indicative, for two reasons. First, the ice model cannot be expected to convert wind stress changes into ice thickness changes with a high level of quantitative skill, because this process is heavily dependent upon the poorly constrained rheological properties of the ice (Feltham 2008; Tsamados et al. 2013). Second, the detailed pattern of the southward trend in modeled ice motion in this region in winter is imperfect (Fig. 8); the observed ice drift trend is toward the Antarctic Peninsula, while the reanalysis wind stress trend (Fig. 11a) drives the ice toward the coast in the eastern Bellingshausen Sea and the Amundsen Sea. However, ice drift trends in autumn are well represented (Fig. 8), and these do drive ice westward in the observations. In summary, the observations strongly support a significant coastal ice thickening in this region, but the model may place it too far east, and with an uncertain magnitude. Massonnet et al. (2013) also model a narrow zone of coastal thickening in this region; Zhang (2014) does not.

\section{Discussion}

The model results presented here reproduce observations of mean ice concentration, drift, and thickness, 

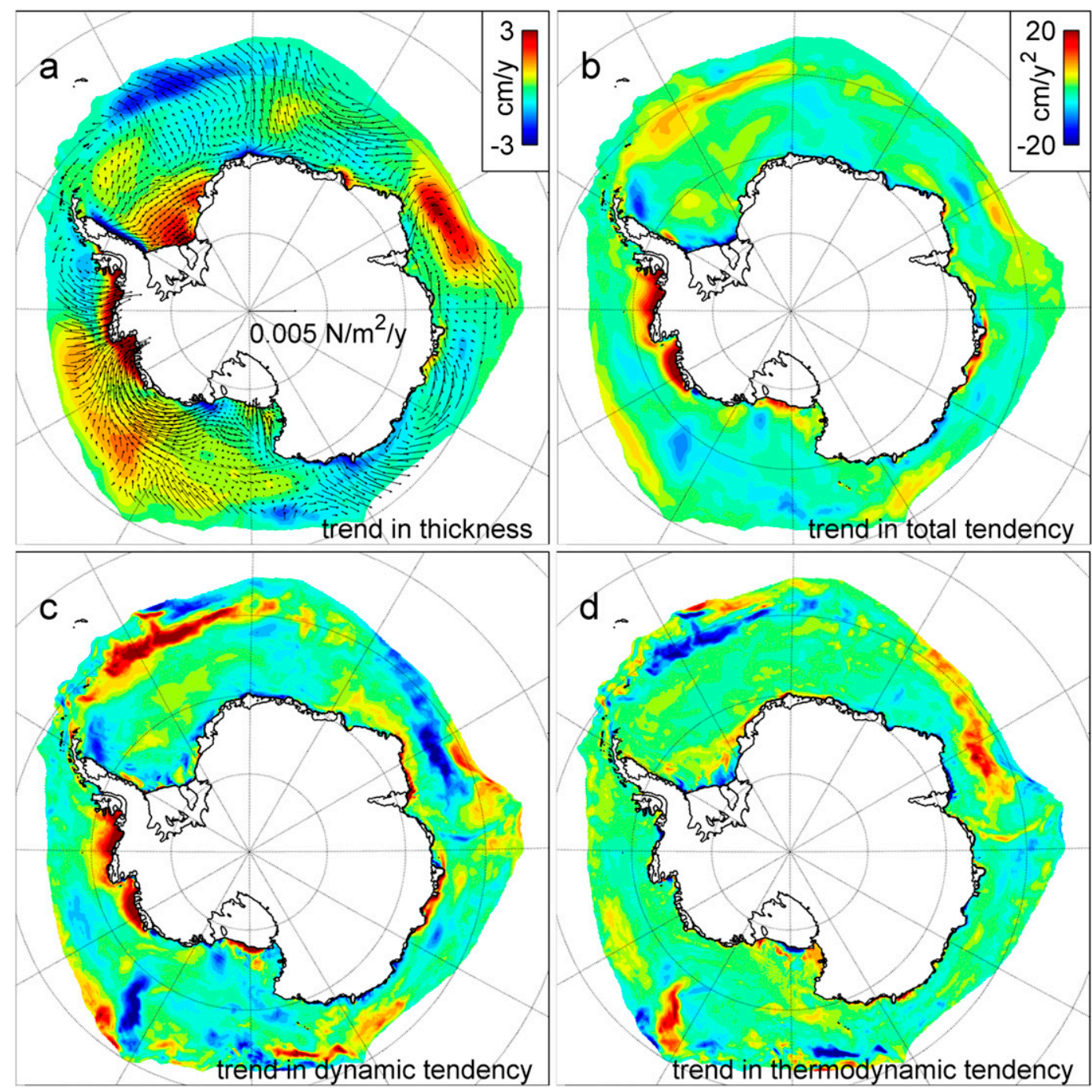

FIG. 11. As in Fig. 10, but for winter [July-September (JAS)].

and trends in ice concentration and drift. The simulated ice thickness trends also agree with those of Massonnet et al. (2013), which can be regarded as a best estimate because of their use of data assimilation. This gives us confidence that the physical processes in the model reflect those operating in reality, offering insight into the processes causing trends in Antarctic sea ice. Holland and Kwok (2012) showed that autumn ice concentration trends are dominated by dynamics in the Pacific sector of the Southern Ocean and thermodynamics elsewhere; this modeling study shows that the same pattern holds for ice thickness, and hence ice volume, in autumn and winter.

This finding has significant consequences. Ice dynamical changes can occur either because the driving stresses have changed, or because the ice is responding differently to a constant stress. The latter can occur if the ice thins, since weaker ice responds more readily to an applied stress, and this is the case in the Arctic, where the ice is accelerating in excess of trends in wind forcing (Kwok et al. 2013). In the Antarctic the trends in ice motion and wind agree closely (Holland and Kwok 2012) and the thickness changes modeled here are much smaller. Thus, the ice-dynamical changes can only be caused by changes air-ice drag and/or ocean-ice drag, which both ultimately result from changes in the winds since surface ocean currents are predominantly wind driven. The dynamic origin of the modeled changes in the Pacific sector in autumn and winter, therefore, implies little or no contribution from changes due to precipitation (Liu and Curry 2010), feedbacks (Stammerjohn et al. 2012; Zhang 2007), or atmosphere or ocean warming (Jacobs and Comiso 1997; Lefebvre and Goosse 2005; Liu et al. 2004). This certainly does not 
rule out a contribution from these mechanisms in summer and spring, or around East Antarctica. A detailed analysis of the trends in ice thermodynamics, in a model capable of accurately representing the warmer seasons, is clearly required to advance this question.

The results also suggest that it is unlikely that increased ice-sheet melting is implicated in the Antarctic sea ice increase, as proposed by Bintanja et al. (2013). The vast majority of increased freshwater discharge from the Antarctic Ice Sheet has entered the Amundsen Sea (Shepherd et al. 2012) and followed the coastal current westward into the Ross Sea, where it has caused a significant freshening (Jacobs and Giulivi 2010). If iceshelf meltwater were to contribute to the sea ice trends, the largest effect would thus be expected to occur in the increasing ice volume in the western Pacific. Our results, and the observational analysis of Holland and Kwok (2012), show quite clearly that the trends in that region are predominantly dynamic in origin in autumn and winter. In addition, the model presented here has no overall trend in ice-sheet meltwater input (the prescribed iceberg discharge is steady, and total ice-shelf melting contains no significant trend), yet is able to reproduce most features of the observed Antarctic ice concentration increase. Thus, our results are in agreement with the study of Swart and Fyfe (2013), who found that the Antarctic sea ice trends were not affected by trends in Antarctic Ice Sheet freshwater flux.

\section{Conclusions}

There are no observations of decadal trends in Antarctic sea ice thickness and volume, so we hindcast them for the period 1992-2010 using a numerical ice-ocean model that is extensively validated against observations. The model accurately simulates mean fields of ice concentration, drift, and thickness in autumn and winter, and reproduces observed trends in ice concentration and drift. This validation allows us to maintain some confidence in the corresponding modeled trends in ice thickness.

Unsurprisingly, the model shows that the observed ice-concentration trends near the ice edge have corresponding trends in ice thickness, with areas of increasing thickness associated with increasing concentration. Model diagnostics show that these thickness trends are driven dynamically in the Pacific sector and thermodynamically elsewhere, in agreement with an observational decomposition of ice concentration trends (Holland and Kwok 2012). The model also reveals that the observed southward trends in ice drift in the Bellingshausen and Weddell Seas have caused ice to thicken near the coast, a trend that does not appear in ice concentration measurements because the ice remains at full cover throughout. The Weddell Sea thickening occurs in response to decreased export early in the year, while the Bellingshausen Sea thickening occurs in winter due to a strong trend toward southward ice flow. These results are the logical extension of known trends in ice concentration, winds, and ice drift. The dynamic origin of the autumn and winter trends in the Pacific sector imply that they must be forced by changes in the winds, rather than other atmospheric or oceanic forcings or feedbacks.

Spatial patterns of increasing and decreasing trends in ice concentration and thickness largely compensate, so that neither variable has a large Antarctic trend overall. Thickening in the interior of the ice pack enhances the overall thickness trend relative to the concentration trend. As fractions of their mean annual values, the modeled increases in Antarctic-wide ice thickness $\left(1.5 \mathrm{~mm} \mathrm{yr}^{-1} \sim\right.$ $\left.0.2 \% \mathrm{yr}^{-1}\right)$ and area $\left(20 \times 10^{3} \mathrm{~km}^{2} \mathrm{yr}^{-1} \sim 0.2 \% \mathrm{yr}^{-1}\right)$ contribute equally to the overall trend in ice volume $\left(30 \mathrm{~km}^{3} \mathrm{yr}^{-1} \sim 0.4 \% \mathrm{yr}^{-1}\right)$. This small gain contrasts markedly with the observed Arctic sea ice volume loss of $\quad 500-1000 \mathrm{~km}^{3} \mathrm{yr}^{-1} \quad\left[\sim(3-6) \% \mathrm{yr}^{-1}\right]$ (Kwok and Rothrock 2009; Laxon et al. 2013). In terms of Southern Ocean freshwater forcing, the small increase in sea ice freshwater extraction is outweighed by the $\sim 70 \mathrm{~km}^{3} \mathrm{yr}^{-1}$ increase in freshwater input from the Antarctic Ice Sheet (Shepherd et al. 2012).

\section{REFERENCES}

Adcroft, A., C. Hill, and J. Marshall, 1997: Representation of topography by shaved cells in a height coordinate ocean model. Mon. Wea. Rev., 125, 2293-2315, doi:10.1175/ 1520-0493(1997)125<2293:ROTBSC >2.0.CO;2.

Bintanja, R., G. J. van Oldenburgh, S. S. Drijfhout, B. Wouters, and C. A. Katsman, 2013: Important role for ocean warming and increased ice-shelf melt in Antarctic sea-ice expansion. Nat. Geosci., 6, 376-379, doi:10.1038/ngeo1767.

Bitz, C. M., P. R. Gent, R. A. Woodgate, M. M. Holland, and R. Lindsay, 2006: The influence of sea ice on ocean heat uptake in response to increasing $\mathrm{CO}_{2}$. J. Climate, 19, 2437-2450, doi:10.1175/JCLI3756.1.

Boyer, T., and Coauthors, 2009: World Ocean Database 2009. NOAA Atlas NESDIS 66, 217 pp. [Available online at ftp:// ftp.nodc.noaa.gov/pub/WOD/DOC/wod09_intro.pdf.]

Bracegirdle, T. J., and G. J. Marshall, 2012: The reliability of Antarctic tropospheric pressure and temperature in the latest global reanalyses. J. Climate, 25, 7138-7146, doi:10.1175/ JCLI-D-11-00685.1.

Bromwich, D. H., and R. L. Fogt, 2004: Strong trends in the skill of the ERA-40 and NCEP-NCAR reanalyses in the high and midlatitudes of the Southern Hemisphere, 1958-2001. J. Climate, 17, 4603-4619, doi:10.1175/3241.1.

, J. P. Nicolas, and A. J. Monaghan, 2011: An assessment of precipitation changes over Antarctica and the Southern Ocean since 1989 in contemporary global reanalyses. J. Climate, 24, 4189-4209, doi:10.1175/2011JCLI4074.1. 
Cavalieri, D. J., and C. L. Parkinson, 2012: Arctic sea ice variability and trends, 1979-2010. The Cryosphere, 6, 881-889, doi:10.5194/ tc-6-881-2012.

Comiso, J. C., 2000: Bootstrap sea ice concentrations from Nimbus-7 SMMR and DMSP SSM/I-SSMIS, version 2 [1992-2010 used]. National Snow and Ice Data Center, Boulder, CO, digital media. [Available online at http://nsidc.org/data/nsidc-0079.]

, and F. Nishio, 2008: Trends in the sea ice cover using enhanced and compatible AMSR-E, SSM/I, and SMMR data. J. Geophys. Res., 113, C02S07, doi:10.1029/2007JC004257.

Dee, D. P., and Coauthors, 2011: The ERA-Interim reanalysis: Configuration and performance of the data assimilation system. Quart. J. Roy. Meteor. Soc., 137, 553-597, doi:10.1002/qj.828.

de Steur, L., D. M. Holland, R. D. Muench, and M. G. McPhee, 2007: The warm-water "Halo" around Maud Rise: Properties, dynamics and impact. Deep-Sea Res. I, 54, 871-896, doi:10.1016/j.dsr.2007.03.009.

Drucker, R., S. Martin, and R. Kwok, 2011: Sea ice production and export from coastal polynyas in the Weddell and Ross Seas. Geophys. Res. Lett., 38, L17502, doi:10.1029/2011GL048668.

Feltham, D. L., 2008: Sea ice rheology. Annu. Rev. Fluid Mech., 40, 91-112, doi:10.1146/annurev.fluid.40.111406.102151.

Fichefet, T., B. Tartinville, and H. Goosse, 2003a: Antarctic sea ice variability during 1958-1999: A simulation with a global ice-ocean model. J. Geophys. Res., 108, 3102, doi:10.1029/ 2001JC001148.

- , H. Goosse, and M. A. M. Maqueda, 2003b: A hindcast simulation of Arctic and Antarctic sea ice variability, 1955-2001. Polar Res., 22, 91-98, doi:10.1111/j.1751-8369.2003.tb00100.x.

Gent, P. R., and J. C. McWilliams, 1990: Isopycnal mixing in ocean circulation models. J. Phys. Oceanogr., 20, 150-155, doi:10.1175/ 1520-0485(1990)020<0150:IMIOCM $>2.0$. CO;2.

Giles, K. A., S. W. Laxon, and A. P. Worby, 2008: Antarctic sea ice elevation from satellite radar altimetry. Geophys. Res. Lett., 35, L03503, doi:10.1029/2007GL031572.

Hellmer, H. H., 2004: Impact of Antarctic ice shelf basal melting on sea ice and deep ocean properties. Geophys. Res. Lett., 31, L10307, doi:10.1029/2004GL019506.

Holland, P. R., and R. Kwok, 2012: Wind-driven trends in Antarctic sea-ice drift. Nat. Geosci., 5, 872-875, doi:10.1038/ ngeo1627.

Hunke, E., and W. H. Lipscomb, 2010: CICE: The Los Alamos sea ice model documentation and software user's manual version 4.1. Los Alamos National Laboratory, LA-CC-06-012, 115 pp.

Jacobs, S. S., and J. C. Comiso, 1997: Climate variability in the Amundsen and Bellingshausen Seas. J. Climate, 10, 697-709, doi:10.1175/1520-0442(1997)010<0697:CVITAA > 2.0.CO;2. , and C. F. Giulivi, 2010: Large multidecadal salinity trends near the Pacific-Antarctic continental margin. J. Climate, 23, 4508-4524, doi:10.1175/2010JCLI3284.1.

- H. H. Helmer, C. S. M. Doake, A. Jenkins, and R. M. Frolich, 1992: Melting of ice shelves and the mass balance of Antarctica. J. Glaciol., 38, 375-387.

Kurtz, N. T., and T. Markus, 2012: Satellite observations of Antarctic sea ice thickness and volume. J. Geophys. Res., 117, C08025, doi:10.1029/2012JC008141.

Kwok, R., and D. A. Rothrock, 2009: Decline in Arctic sea ice thickness from submarine and ICESat records: 1958-2008. Geophys. Res. Lett., 36, L15501, doi:10.1029/2009GL039035.

, A. Schweiger, D. A. Rothrock, S. Pang, and C. Kottmeier, 1998: Sea ice motion from satellite passive microwave imagery assessed with ERS SAR and buoy motions. J. Geophys. Res., 103, 8191-8214, doi:10.1029/97JC03334.
_ - G. Spreen, and S. Pang, 2013: Arctic sea ice circulation and drift speed: Decadal trends and ocean currents. J. Geophys. Res., 118, 2408-2425, doi:10.1002/jgrc.20191.

Large, W. G., J. C. McWilliams, and S. C. Doney, 1994: Oceanic vertical mixing-A review and a model with a nonlocal boundary-layer parameterization. Rev. Geophys., 32, 363-403, doi:10.1029/94RG01872.

_ , G. Danabasoglu, S. C. Doney, and J. C. McWilliams, 1997: Sensitivity to surface forcing and boundary layer mixing in a global ocean model: Annual-mean climatology. J. Phys. Oceanogr., 27, 2418-2447, doi:10.1175/1520-0485(1997)027<2418: $\mathrm{STSFAB}>2.0 . \mathrm{CO} ; 2$

Laxon, S. W., and Coauthors, 2013: CryoSat-2 estimates of Arctic sea ice thickness and volume. Geophys. Res. Lett., 40, 732-737, doi:10.1002/grl.50193.

Lefebvre, W., and H. Goosse, 2005: Influence of the Southern Annular Mode on the sea ice-ocean system: The role of the thermal and mechanical forcing. Ocean Sci., 1, 145-157, doi:10.5194/os-1-145-2005.

— , and 2008: An analysis of the atmospheric processes driving the large-scale winter sea ice variability in the Southern Ocean. J. Geophys. Res., 113, C02004, doi:10.1029/ 2006JC004032.

Leith, C. E., 1996: Stochastic models of chaotic systems. Physica D, 98, 481-491, doi:10.1016/0167-2789(96)00107-8.

Lindsay, R. W., D. M. Holland, and R. A. Woodgate, 2004: Halo of low ice concentration observed over the Maud Rise seamount. Geophys. Res. Lett., 31, L13302, doi:10.1029/2004GL019831.

Liu, J. P., and J. A. Curry, 2010: Accelerated warming of the Southern Ocean and its impacts on the hydrological cycle and sea ice. Proc. Natl. Acad. Sci. USA, 107, 14987-14992, doi:10.1073/pnas.1003336107.

- — - and D. G. Martinson, 2004: Interpretation of recent Antarctic sea ice variability. Geophys. Res. Lett., 31, L02205, doi:10.1029/2003GL018732.

Losch, M., 2008: Modeling ice shelf cavities in a z coordinate ocean general circulation model. J. Geophys. Res., 113, C08043, doi:10.1029/2007JC004368.

_ D. Menemenlis, J. M. Campin, P. Heimbach, and C. Hill, 2010: On the formulation of sea-ice models. Part 1: Effects of different solver implementations and parameterizations. Ocean Modell., 33, 129-144, doi:10.1016/j.ocemod.2009.12.008.

Mahlstein, I., P. R. Gent, and S. Solomon, 2013: Historical Antarctic mean sea ice area, sea ice trends, and winds in CMIP5 simulations. J. Geophys. Res. Atmos., 118, 5105-5110, doi:10.1002/jgrd.50443.

Markus, T., R. Massom, A. Worby, V. Lytle, N. Kurtz, and T. Maksym, 2011: Freeboard, snow depth and sea-ice roughness in East Antarctica from in situ and multiple satellite data. Ann. Glaciol., 52, 242-248, doi:10.3189/172756411795931570.

Marshall, J., A. Adcroft, C. Hill, L. Perelman, and C. Heisey, 1997: A finite-volume, incompressible Navier-Stokes model for studies of the ocean on parallel computers. J. Geophys. Res., 102, 5753-5766, doi:10.1029/96JC02775.

Massonnet, F., P. Mathiot, T. Fichefet, H. Goosse, C. K. Beatty, M. Vancoppenolle, and T. Lavergne, 2013: A model reconstruction of the Antarctic sea ice thickness and volume changes over 1980-2008 using data assimilation. Ocean Modell. 64, 67-75, doi:10.1016/j.ocemod.2013.01.003.

Mathiot, P., C. K. Beatty, T. Fichefet, H. Goosse, F. Massonnet, and M. Vancoppenolle, 2012: Better constraints on the sea-ice state using global sea-ice data assimilation. Geosci. Model Dev., 5, 1501-1515, doi:10.5194/gmd-5-1501-2012. 
McDougall, T. J., D. R. Jackett, D. G. Wright, and R. Feistel, 2003: Accurate and computationally efficient algorithms for potential temperature and density of seawater. J. Atmos. Oceanic Technol., 20, 730-741, doi:10.1175/1520-0426(2003)20<730: AACEAF $>2.0 . \mathrm{CO} ; 2$.

Menemenlis, D., and Coauthors, 2005: NASA supercomputer improves prospects for ocean climate research. Eos, Trans. Amer. Geophys. Union, 86, 89-96, doi:10.1029/2005EO090002.

Orsi, A. H., T. Whitworth, and W. D. Nowlin, 1995: On the meridional extent and fronts of the Antarctic Circumpolar Current. DeepSea Res. I, 42, 641-673, doi:10.1016/0967-0637(95)00021-W.

Ozsoy-Cicek, B., S. F. Ackley, H. Xie, D. Yi, and H. J. Zwally, 2013: Sea ice thickness retrieval algorithms based on in situ surface elevation and thickness values for application to altimetry. J. Geophys. Res., 118, 3807-3822, doi:10.1002/jgrc.20252.

Parkinson, C. L., and D. J. Cavalieri, 2012: Antarctic sea ice variability and trends, 1979-2010. The Cryosphere, 6, 871-880, doi:10.5194/tc-6-871-2012.

Petty, A. A., P. R. Holland, and D. L. Feltham, 2013: Sea ice and the ocean mixed layer over the Antarctic shelf seas. The Cryosphere, 7, 4321-4377, doi:10.5194/tcd-7-4321-2013.

Polvani, L. M., and K. L. Smith, 2013: Can natural variability explain observed Antarctic sea ice trends? New modeling evidence from CMIP5. Geophys. Res. Lett., 40, 3195-3199, doi:10.1002/grl.50578.

Powell, D. C., T. Markus, and A. Stossel, 2005: Effects of snow depth forcing on Southern Ocean sea ice simulations. J. Geophys. Res., 110, C06001, doi:10.1029/2003JC002212.

Semtner, A., 1976: A model for the thermodynamic growth of sea ice in numerical investigations of climate. J. Phys. Oceanogr., 6, 379-389, doi:10.1175/1520-0485(1976)006<0379: AMFTTG $>2.0 . \mathrm{CO} ; 2$.

Shepherd, A., and Coauthors, 2012: A reconciled estimate of icesheet mass balance. Science, 338, 1183-1189, doi:10.1126/ science. 1228102 .

Sigmond, M., and J. C. Fyfe, 2010: Has the ozone hole contributed to increased Antarctic sea ice extent? Geophys. Res. Lett., 37, L18502, doi:10.1029/2010GL044301.

Sokolov, S., and S. R. Rintoul, 2009: Circumpolar structure and distribution of the Antarctic Circumpolar Current fronts: 1. Mean circumpolar paths. J. Geophys. Res., 114, C11018, doi:10.1029/2008JC005108.

Stammerjohn, S. E., D. G. Martinson, R. C. Smith, X. Yuan, and D. Rind, 2008: Trends in Antarctic annual sea ice retreat and advance and their relation to El Niño-Southern Oscillation and Southern Annular Mode variability. J. Geophys. Res., 113, C03S90, doi:10.1029/2007JC004269.

_ - R. Massom, D. Rind, and D. G. Martinson, 2012: Regions of rapid sea ice change: An inter-hemispheric seasonal comparison. Geophys. Res. Lett., 39, L06501, doi:10.1029/ 2012 GL050874.

Stossel, A., Z. R. Zhang, and T. Vihma, 2011: The effect of alternative real-time wind forcing on Southern Ocean sea ice simulations. J. Geophys. Res., 116, C11021, doi:10.1029/ 2011JC007328.

Swart, N. C., and J. C. Fyfe, 2013: The influence of recent Antarctic ice sheet retreat on simulated sea ice area trends. Geophys. Res. Lett., 40, 4328-4332, doi:10.1002/grl.50820.

Timmermann, R., and A. Beckmann, 2004: Parameterization of vertical mixing in the Weddell Sea. Ocean Modell., 6, 83-100, doi:10.1016/S1463-5003(02)00061-6.
,-- , and H. H. Hellmer, 2002: Simulations of ice-ocean dynamics in the Weddell Sea 1 . Model configuration and validation. J. Geophys. Res., 107 (C3), doi:10.1029/2000JC000741.

- A. Worby, H. Goosse, and T. Fichefet, 2004: Utilizing the ASPeCt sea ice thickness data set to evaluate a global coupled sea ice-ocean model. J. Geophys. Res., 109, C07017, doi:10.1029/2003JC002242.

, H. Goosse, G. Madec, T. Fichefet, C. Ethe, and V. Duliere, 2005: On the representation of high latitude processes in the ORCA-LIM global coupled sea ice-ocean model. Ocean Modell., 8, 175-201, doi:10.1016/j.ocemod.2003.12.009.

S. Danilov, J. Schroter, C. Boning, D. Sidorenko, and K. Rollenhagen, 2009: Ocean circulation and sea ice distribution in a finite element global sea ice-ocean model. Ocean Modell., 27, 114-129, doi:10.1016/j.ocemod.2008.10.009.

_ and Coauthors, 2010: A consistent data set of Antarctic ice sheet topography, cavity geometry, and global bathymetry. Earth Syst. Sci. Data, 2, 261-273, doi:10.5194/essd-2-261-2010.

Tsamados, M., D. L. Feltham, and A. V. Wilchinsky, 2013: Impact of a new anisotropic rheology on simulations of Arctic sea ice. J. Geophys. Res. Oceans, 118,91-107, doi:10.1029/2012JC007990.

Turner, J., and Coauthors, 2009: Non-annular atmospheric circulation change induced by stratospheric ozone depletion and its role in the recent increase of Antarctic sea ice extent. Geophys. Res. Lett., 36, L08502, doi:10.1029/2009GL037524.

, T. J. Bracegirdle, T. Phillips, G. J. Marshall, and J. S. Hosking, 2013: An initial assessment of Antarctic sea ice extent in the CMIP5 models. J. Climate, 26, 1473-1484, doi:10.1175/ JCLI-D-12-00068.1.

Visbeck, M., J. Marshall, and H. Jones, 1996: Dynamics of isolated convective regions in the ocean. J. Phys. Oceanogr., 26, 1721-1734, doi:10.1175/1520-0485(1996)026<1721:DOICRI > 2.0.CO;2.

Wang, Z., and M. P. Meredith, 2008: Density-driven Southern Hemisphere subpolar gyres in coupled climate models. Geophys. Res. Lett., 35, L14608, doi:10.1029/2008GL034344.

Worby, A. P., C. A. Geiger, M. J. Paget, M. L. Van Woert, S. F. Ackley, and T. L. DeLiberty, 2008: Thickness distribution of Antarctic sea ice. J. Geophys. Res., 113, C05S92, doi:10.1029/ 2007JC004254.

Xie, H., A. E. Tekeli, S. F. Ackley, D. Yi, and H. J. Zwally, 2013: Sea ice thickness estimations from ICESat altimetry over the Bellingshausen and Amundsen Seas, 2003-2009. J. Geophys. Res. Oceans, 118, 2438-2453, doi:10.1002/jgrc.20179.

Zhang, J. L., 2007: Increasing Antarctic sea ice under warming atmospheric and oceanic conditions. J. Climate, 20, 2515-2529, doi:10.1175/JCLI4136.1.

, 2014: Modeling the impact of wind intensification on Antarctic sea ice volume. J. Climate, 27, 202-214, doi:10.1175/ JCLI-D-12-00139.1.

Zunz, V., H. Goosse, and F. Massonnet, 2013: How does internal variability influence the ability of CMIP5 models to reproduce the recent trend in Southern Ocean sea ice extent? The Cryosphere, 7, 451-468, doi:10.5194/tc-7-451-2013.

Zwally, H. J., J. C. Comiso, C. L. Parkinson, D. J. Cavalieri, and P. Gloersen, 2002: Variability of Antarctic sea ice 1979-1998. J. Geophys. Res., 107, 3041, doi:10.1029/2000JC000733.

, D. H. Yi, R. Kwok, and Y. H. Zhao, 2008: ICESat measurements of sea ice freeboard and estimates of sea ice thickness in the Weddell Sea. J. Geophys. Res., 113, C02S15, doi:10.1029/2007JC004284. 